\title{
Three Courses of Tianjiu Therapy in Sanfu Days for Chronic Asthma: A Clinic Efficacy Observation Trail
}

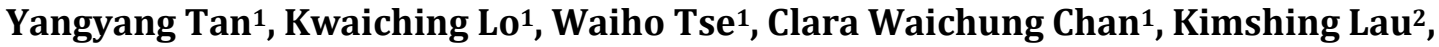 \\ Stacey S. Cherny ${ }^{3}$, Lixing Lao' ${ }^{1}$, Lei Li ${ }^{*}$ \\ ${ }^{1}$ School of Chinese Medicine, The University of Hong Kong, Hong Kong, China \\ ${ }^{2}$ Department of Respiratory Medicine, Ruttonjee Hospital, Hong Kong, China \\ ${ }^{3}$ Department of Psychiatry, The University of Hong Kong, Hong Kong, China \\ Email: *llie@hku.hk
}

How to cite this paper: Tan, Y.Y., Lo, K.C., Tse, W.H., Chan, C.W.C., Lau, K.S., Cherny, S.S., Lao, L.X. and Li, L. (2017) Three Courses of Tianjiu Therapy in Sanfu Days for Chronic Asthma: A Clinic Efficacy Observation Trail. Chinese Medicine, 8, 43-71. https://doi.org/10.4236/cm.2017.82005

Received: February 15, 2017

Accepted: June 20, 2017

Published: June 23, 2017

Copyright $\odot 2017$ by authors and Scientific Research Publishing Inc. This work is licensed under the Creative Commons Attribution International License (CC BY 4.0).

http://creativecommons.org/licenses/by/4.0/

\begin{abstract}
Objective: This study was aimed to compare the efficacy among chronic asthma patients who received 1 course treatment, 2 courses treatment and 3 courses treatment of Tianjiu Therapy in Sanfu Days. Methods: This study was comparing efficiency with 3 courses (baseline, the 1st course, the 2 nd course, the 3rd course) of Tianjiu Therapy for asthma in 91 chronic asthma patients. For each course, patients received 3 times Tianjiu Therapy treatments, pretreatment assessment and posttrestment assessment. Results: 91 asthma participants completed at least 3 courses of Tianjiu Therapy in Sanfu Days. 1) Days for asthma attacked during the last 12 months; the frequency for asthma attacked during the last 12 months; incidence of admitting to clinic (Integrated Chinese Medicine \& Western Medicine Clinic) when asthma attack during the last 12 months; times of admitting to clinic; times of solving by persistent medicine; times of solving by own medicine when asthma attack during the last 12 months; and symptoms associated with Chinese medicine of waking by asthma symptoms, lack of strength, lassitude, rapid or difficult breathing were improved at the 1 st course, the 2 nd course and the 3 rd course compared with baseline (All $P<0.05$ ); 2) The incidence of admitting to In-patient Hospital and solving by persistent prescription when asthma attacked; the frequency of Chinese Herbal Medicine used during Tianjiu Therapy; the status of asthma under controlled and no improved by self-evaluation were similarly improved at the 2 nd course and the 3 rd course (All $P<0.05$ ); 3) Incidence of admitting to A \& E for asthma attacked during the last 12 months, and other treatments except Western Medicine, Chinese Herbal Medicine, and Acupuncture \& Moxibution during the last 12 months were improvement at the 3 rd course (All $P<0.05$ ); 4) Symptoms associated with
\end{abstract}


Chinese medicine of spontaneous sweating and reduction of exercise were improved at the 1 st course $(P<0.05) ; 5)$ Symptom of diarrhea after intake of oil food was became a little bad at the 2 nd course and the 3 rd course $(P<$ $0.05)$; 6) The frequency of bronchodilator used when asthma attack was reduced in the 1 st course and the 2nd course (All $P<0.05$ ); 7) Lung function of FEV1 and FEV1/FVC $(\times 100)$ were a little improvement, but have no significant statistical difference $(P>0.05) ; 8)$ The total score of ACT at the 1 st course, the 2 nd course, and the 3 rd course did not improved significantly (All $P>0.05)$. Conclusion: After Tianjiu Therapy in Sanfu Days participants have achieved good efficiency, and as the course get longer, the efficiency of more symptoms associated with chronic asthma were improved. Suggest patients with chronic asthma continuous receive Tianjiu Therapy in Sanfu Days which will be a feasible treatment.

\section{Keywords}

Tianjiu Therapy, Sanfu Days, Asthma

\section{Introduction}

Bronchial asthma is a chronic airway inflammatory disease, which belongs to "asthma disease" of the Traditional Chinese Medicine [1], performance of breathing difficulties, even open mouth and carry up shoulder. Western Medicine for the treatment of asthma, $\beta 2$-adrenoceptor agonist are the first-line drug for diastolic bronchospasm, mainly stay on the stage of focusing on the application of glucocorticoid to prevent airway remodeling stage, but glucocorticoids are still not fully meet the clinical needs [2]. It has a long history in the struggle with asthma disease of Traditional Chinese Medicine (TCM).

Modern research proved, acupoint sticking could enhance the body's non-specific immune function and function of pituitary-adrenal cortex system, reduce the body's allergic condition, achieve the effect of anti-allergic, and could remove bronchospasm and promote exudate absorption directly, so as to relieve asthma attack [3]. Tianjiu Therapy is sticking external specific acupoints and trouble place by certain Chinese medicine and trouble place, make local hyperemia, blister, or even fester, like post-moxibustion sore to treat disease, it is a kind of unti-hot moxibustion therapy [4]. Sanfu Days are the highest temperature days through a year, start from summer solstice, according to the arrangement of Heavenly Stems and Earthly Branches, the third Geng-ri is the first Fu Day, the forth Geng-ri is the second Fu Day, and the first Geng-ri after the beginning of autumn is the last Fu Day. Tianjiu Therapy in Sanfu Days for asthma follows the rule of the external treatment to cure internal disease and the methods of curing winter disease in summer of TCM. Tianjiu Therapy in Sanfu Days has a very special characteristic of medical timing of treatment therapy, on Sanfu Days, Positive-qi of nature and human body is most strongest in the year, stick herbal cake made up of some medicine with the feature of spicy and hot, 
stimulating on the acupuncture point, to achieve the purpose of regulating Yin and Yang, preventing and curing of disease through the function of both acupuncture point stimulation and drug infiltration absorption. It is widely used in the treatment of asthma and other cold symptoms because the operation is simple, safe and reliable, lasting for many years in the clinical curative effect [5]. In recent years, with the deepening study, Tianjiu Therapy in Sanfu Days has got great progress with asthma controlled. Now it was widely applied in the clinical treatment of asthma as the curative effect of Tianjiu Therapy was widely recognized, and more and more people are receive this treatment method for prevention and treatment of asthma [6]-[14]. We have already conducted an initial trail which compared 1 year of Tainjiu Therapy treatment with placebo control group, and a clinical trial which compared two years versus 1 year Tianjin Therapy in Sanfu Days for chronic asthma [15] [16]. In the first study, it was found that Tianjiu Therapy can reduce the need for medications to control asthma, improved the low quality of life with asthma patients; In the second study, it was proved that the effect of 2 years Tianjiu Therapy was not as effective as 1 year such treatment for asthma, but the second year Tianjiu Therapy was still need because it has a role to consolidate the curative effect of Tianjiu Therapy for asthma. In the previous two studies, the efficiency of Tianjiu Therapy in Sanfu Days for asthma was proved, but the optimal treatment duration is still unknown. Hence this study was aimed to compare the efficacy among chronic asthma patients who received 1 course treatment, 2 courses treatment and 3 courses treatment of Tianjiu Therapy in Sanfu Days.

\section{Methods}

\subsection{Enrollment Criteria}

Asthma patients were recruited from the Orthopedics-Traumatology, Acupuncture and Tui-na Clinical Centre for Teaching and Research, School of Chinese Medicine, The University of Hong Kong.

The patients are in both gender above 13 years old, and the participants must be diagnosed asthma before and have symptoms associated with chronic asthma in the past 12 months. In addition, all patients were needed to meet the following inclusion criteria: difficulty breathing; episodic symptoms of airflow obstruction; symptoms occurring or worsening at night; symptoms awakening the patients at night; chest tightness; cough (worse at night); symptoms occurring or worsening with exercise, viral infections, changes in weather and strong emotions. Patients would be excluded according to one or more of the following exclusion criteria: acute asthma attack; fever and pharyngitis; pregnancy; severe cardiac and pulmonary diseases; tuberculosis; severe heart diseases or with pacemaker; bleeding disorders; keloid; allergy to topical medication; hypersensitive skin condition; diabetes mellitus. And all patients who took part in the study needed to sign consent inform by themselves or their legal guardian (younger than 18 years old). 


\subsection{Study Design}

In this study, participants totally completed at least 3 treatment courses of Tianjiu Therapy in Sanfu Days, pretreatment assessment and posttreatment assessment from 2010 to 2015. Every treatment course consisted 3 treatment sessions (3 treatment sessions were conducted in Sanfu Days in every year: for example, 19 July, 29 July and 8 August 2010 respectively). Both pretreatment assessment and posttreatment assessment included pulmonary function, questionnaires, and ACTs.

Baseline was set at before the first treatment course; Patients 1 year after the first course treatment and before the second course was set as the $1^{\text {st }}$ course; $\mathrm{Pa}$ tients 1 year after the second course treatment and before the third course was set as the $2^{\text {nd }}$ course; Patients 1 year after the third course treatment and before the forth course was set the $3^{\text {rd }}$ course.

All questionnaires (Table 1), ACTs (Asthma Control Test) and lung-function test were completed by face to face interview before every session. Patients must completed 3 treatment courses from 2010 to 2015 (Table 1), and they also must have completed all pretreatment assessments and posttreatment assessments. There were 48 continuous participants and 43 discontinuous participants among the 91 patients. This study conducted a subgroup analysis for continuous group and discontinuous group, but nothing different was found in most of the outcome measurements. Hence this study combined two groups above as study subjects.

The three treatment times from 2010 to 2015 were as follow:

July19, July 29, and August 8, 2010;

July 14, July 24, and August 13, 2011;

July18, July 28, and August 7, 2012;

July 13, July 23, and August 12, 2013;

July18, July 27, and August 14, 2014;

Table 1. Patients distribution.

\begin{tabular}{lccc}
\hline Year of patients completed & Patients & Year of patients completed & Patients \\
\hline $2010-2011$ and 2012-2013 & 6 & $2010-2011-2012-2013-2014$ & 5 \\
$2010-2011$ and 2012-2014 & 1 & $2010-2011-2012-2013-2015$ & 2 \\
$2010-2011$ and 2012-2015 & 2 & $2010-2011-2012-2014-2015$ & 1 \\
$2010-2011$ and 2013-2014 & 6 & $2010-2011-2013-2014-2015$ & 5 \\
$2010-2011$ and 2014-2015 & 2 & $2010-2012-2013-2014-2015$ & 3 \\
$2010-2012$ and 2013-2014 & 5 & $2010-2011-2012-2013-2014-2015$ & 12 \\
$2010-2013$ and 2014-2015 & 10 & $2011-2013-2014-2015$ & 3 \\
$2011-2012$ and 2013-2014 & 1 & $2011-2012-2013-2014-2015$ & 11 \\
$2011-2012$ and 2013-2015 & 1 & & \\
$2011-2012$ and 2014-2015 & 4 & & \\
$2012-2013$ and 2014-2015 & 11 & & \\
\hline
\end{tabular}


July 13, July 23, and August 12, 2015.

11 acupoints were selected for attached by sticking patches: DU14, DU12, DU4, BL13 (both side), BL23 (both sides), BL43 (both sides) and EX-B1 (both sides) (Figure 1).

The formula mixed herbs was a combination of the record in the "Zhang's Medicine" and the formula was frequency used in clinical trials just now, the proportion was 2:1:1:1:1:1:1:1: Sinapi Alba 120g, Radix Corydalis Yanhusuo $60 \mathrm{~g}$, Processed Euphorbia kansui 60 g, Asari Herba cum Radice 60 g, Ephedrae Herba 60 g, Processed Radix Aconiti Praeparata 60 g, Cinnamomum cassia $60 \mathrm{~g}$ and Eugenia caryophyllata $60 \mathrm{~g}$. These are for around 100 participants used. All of them were milled in to powder and mixed together by ginger juice, and then was made into pieces of cake-like objects, every piece was about 2 grams.

Every acupoint was applied one piece of the herbs, the herbs was stuck in skin by approximately $4 \mathrm{~cm} \times 4 \mathrm{~cm}$ hypoallergenic tape $(3 \mathrm{M}$ Micropore Tape 1535-3).

\subsection{Outcome Measures}

Lung function included: FEV1, FEV1/FVC (\%).

ACT included: In the past 4 weeks, 1) the times of asthma keep participants from getting as much done at work, school or at home, and 2) the frequency of shortness of breath, and 3) the frequency of asthma symptoms (whee zing, coughing, shortness of breath, chest tightness or pain) wake up at night or earlier than usual in the morning, 4) the frequency of using rescue inhaler or

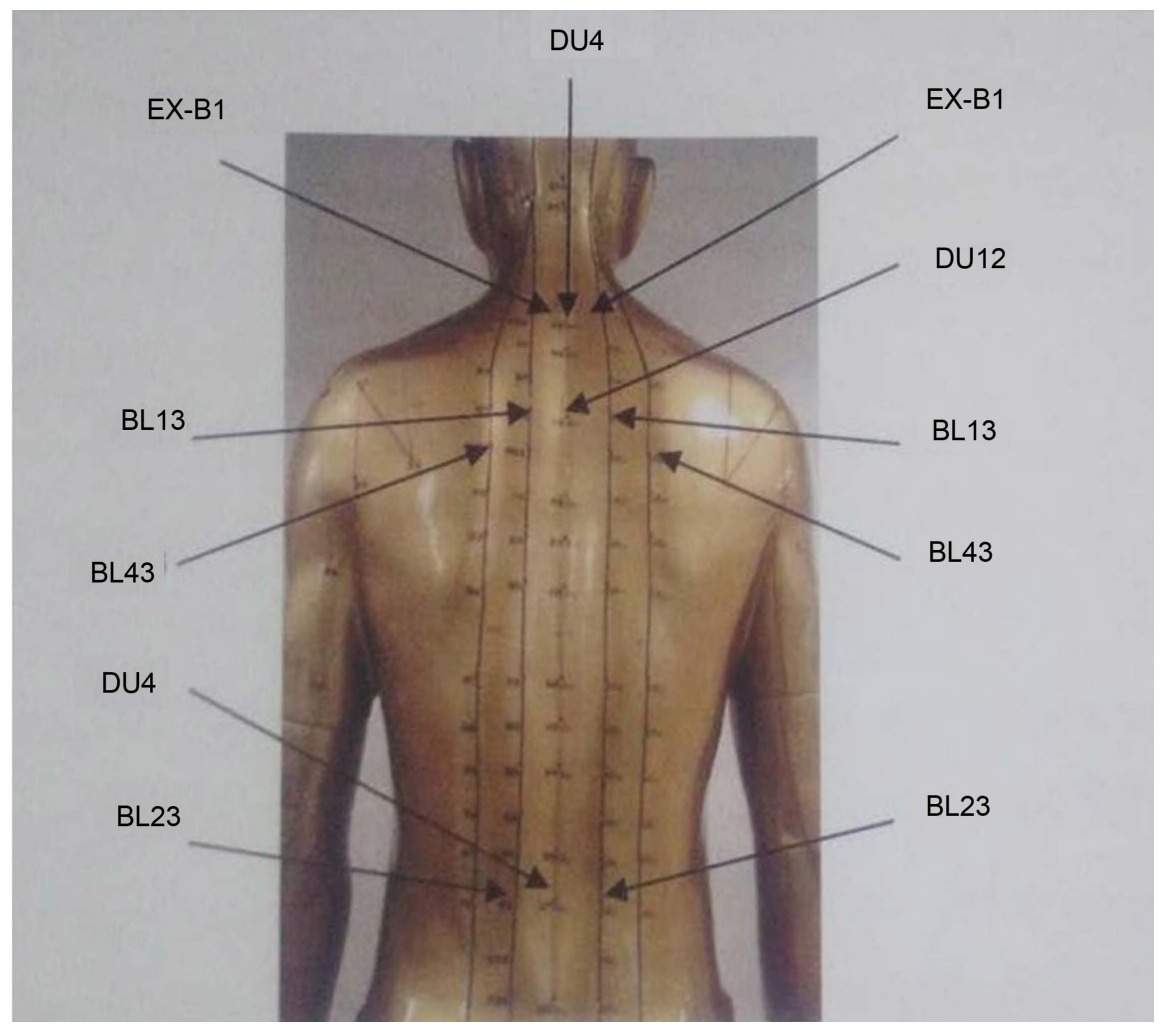

Figure 1. Acupoints selected for Tianjiu Therapy in Sanfu Days. 
nebulizer medication (such as albuterol), and 5) the rate of the asthma wad controlled. Participants could fill 1-5 scores for every question.

The questionnaire could be filled physicians "zero" when the participant wanted to fill "NO", and filled " 1 " when they wanted to fill "YES", For example: "Did you use any Western Medicine when paroxysm in the past 12 months?" if the answer is "YES", then got " 1 " score, if the answer is "NO", then got " 0 " score.

Questionnaire included: 1) Asthma first attacked time; 2) Courses of asthma attacked; 3)The frequency and extent of asthma attacked in the past 12 months; 4) Condition of bronchodilator used when asthma attacked in the past 12 months; 5) Situation of asthma care and emergency in the past 12 months; 6) Treatment other than Western Medicine for asthmas in the past 12 months; 7) Asthma under controlled self-evaluation; 8) Cases of 23 asthma symptoms improved or not in the past 12 months.

\subsection{Statistical Analysis}

Statistical analyses were performed with the Statistical Package for the Social Sciences (SPSS) software program (version 21) for Windows 8.

The data analysized included baseline, the $1^{\text {st }}$ course, the $2^{\text {nd }}$ course, and the $3^{\text {rd }}$ course. Lung function: FEV1, FEV1/FVC (\%), and the number of days for asthma signs, the number of days for using any Western Medicine were tested by Nonparametric tests (Friedman Test), the value of the best efficient course was tested by Nonparametric tests (Wilcoxon Signed Test 2 Related-Samples), description analysis was conducted for the percentage of patients with twentythree symptoms associated with asthma, the percentage of asthma healthy care, the percentage of bronchodilator used, and the percentage of asthma attack.

\section{Results}

There are 1516 person-time with chronic asthma were recruited from 2010 to 2015: 323 in 2010, 391 in 2011, 283 in 2012, 206 in 2013, 164 in 2014, and 149 in 2015, among them 910 person-time completed Tianjiu Therapy (242 in 2010, 169 in 2011, 132 in 2012, 149 in 2013, 117 in 2014, and 101 in 2015), and among the 910 person-time, 179 participants completed one course Tianjiu Therapy, 77 participants completed two courses, 54 participants completed three courses, 52 participants completed four courses, 27 participants completed five courses Tianjiu Therapy, 12 participants completed six courses, there were 401 participants completed at least one course Tianjiu Therapy. Patients would be excluded for the final statistical analysis due to the incomplete data. The cause of incomplete data included incomplete treatments, during treatment period participants illness, asthma exacerbation, losing contact, pregnancy, inability to participate timely, refusing to participate, did not in Hong Kong, or incomplete ACT, questionnaire, lung function test. The participants can be included for the final analysis only when they have seven time points' data (the $1^{\text {st }}$ course pre and post-assessment, the $2^{\text {nd }}$ course pre and post-assessment, the $3^{\text {rd }}$ course pre and postassessment, the $4^{\text {th }}$ course pre-assessment). Overall, from 2010 to 2015, patients 
who received three-course Tianjiu Therapy in Sanfu Days were 91.

For the baseline characteristics of the 91 participants, the average age was $50 \pm$ 15.26 (14 to 93 ) years old, $33 \%$ was male, $67 \%$ was female; the average onset age was $32.78 \pm 22.99$ ( 1 to 93 ) years old; and the average courses of asthma attacked was $19.98 \pm 17.90$ ( 1 to 93 ) (Table 2 ).

In baseline, in the past 12 months, the number of days patients subjected asthma-related symptoms was: $106.49 \pm 142.83$, and means ( \pm SD) of FEV1 was $1.85 \pm 0.94$, and the mean ratio of FEV1 to forced vital capacity (FVC) was 81.68 \pm 19.06 . The percentage of participants had been hospitalized and admitted to A \& E at least once for an asthma-related event was $22 \%$ and $15.4 \%$ respectively; the percentage of participants had been clinic visit and persistent prescription was $81.3 \%$ and $86.8 \%$ respectively; the percentage of participants had been by own medication was $13.2 \%$; and the percentage of participants had not been processed was 9.9\%; the frequency of bronchodilator never used in past 12 months was $8.9 \%$ (Table 3). For the specific twenty-three such symptoms: patients suffered: 1 . wind intolerance was $27.9 \% ; 2$. susceptible to cold was $27 \% ; 3$. sneeze, running nose before onset was $22.5 \%$; 4 . onset during quarter turn was $29.3 \%$; 5 . rapid or difficult breathing was $18.4 \%$; 6 . wake up by asthma symptoms was $24.7 \%$; 7. bluish complexion was $37.5 \%$; 8 . spontaneous sweating was $26.8 \%$; 9. Lassitude was $9.5 \%$; 10. lack of speech was $12 \%$; 11 . decline in physical strength was $13 \%$; 12 . reduction of exercise was $24.1 \%$; 13 . lack of strength was $28.4 \%$; 14 . lack of energy after asthma was $23.3 \%$; 15 . poor appetite was $29.2 \%$; 16. abdomen fullness was $29.4 \%$; 17 . sloopy stool was $35 \%$; 18 . diarrhea after intake of oily food was $37.5 \%$; 19 . fear of cold was $25.7 \%$; 20 . soreness and weakness of waist and was $28.4 \%$; 21 . tinnitus was $28.6 \% ; 22$. frequent urination/night was $33.3 \%$; 23. redness, hotness was $33.3 \%$ (Table 4 ).

\subsection{Response to Intervention}

\subsubsection{The Incidence of Asthma Attack in the Past 12 Months}

The incidence of asthma attack in the past 12 months declined from $29.4 \%$ in baseline to $26.1 \%$ in the $1^{\text {st }}$ course, and $21.6 \%$ in the $2^{\text {nd }}$ course, and $22.9 \%$ in the $3^{\text {rd }}$ course. After treatment, the efficiency of acute asthma attack has significant difference among the 4 time points $(P<0.05)$ (Table 3$)$, the $1^{\text {st }}$ course was improved $(P<0.01)$, the $2^{\text {nd }}$ course and the $3^{\text {rd }}$ course improved significant (All $P<$

Table 2. Characteristics of Parcitipants.

\begin{tabular}{cc}
\hline Characteristic & Average \\
Age-year & $50 \pm 15.26$ \\
Gender-no. (\%) & \\
Male & $33(36.30)$ \\
Female & $68(63.70)$ \\
Course of disease-year & $19.98 \pm 17.90$ \\
Onset age & $32.78 \pm 22.99$ \\
\hline
\end{tabular}


Table 3. Characteristics of Parcitipants.

\begin{tabular}{|c|c|c|c|c|c|c|c|}
\hline Variable & baselin & $\begin{array}{l}\text { The 1st } \\
\text { course }\end{array}$ & $\begin{array}{l}\text { The } 2 \text { nd } \\
\text { course }\end{array}$ & $\begin{array}{l}\text { The } 3 \text { rd } \\
\text { course }\end{array}$ & \multicolumn{2}{|l|}{$P$ value } & $\mathrm{CI}$ \\
\hline \multicolumn{8}{|c|}{ Acute asthma attack in past year-no. (\%) } \\
\hline & & $91(29.4)$ & $81(26.1)$ & $67(21.6)$ & $71(22.9)$ & $0.000^{\# \# \#}$ & 21.563 \\
\hline \multicolumn{8}{|c|}{ Days for asthma-related symptoms in last 12 months-(means \pm SD) } \\
\hline \multicolumn{3}{|r|}{$106.49 \pm 142.83$} & $\begin{array}{c}66.22 \pm \\
110.68\end{array}$ & \multicolumn{2}{|c|}{$42.49 \pm 81.5142 .31 \pm 88.82$} & $0.000^{\# \# \#}$ & \\
\hline \multicolumn{8}{|c|}{ Pulmonary function test } \\
\hline & & $1.85 \pm 0.94$ & $1.73 \pm 0.67$ & $1.92 \pm 1.51$ & $1.80 \pm 0.98$ & 0.233 & \\
\hline & & $81.68 \pm 19.06$ & $82.76 \pm 14.89$ & $83.37 \pm 14.60$ & $79.50 \pm 19.17$ & 0.221 & \\
\hline \multicolumn{8}{|c|}{ Asthma-related health care in last 12 months-no. (\%) } \\
\hline$\geq 1$ Admit $t$ & $\mathrm{~A} \& \mathrm{E}$ & $20(22)$ & $10(11)$ & $10(11)$ & $6(6.6)$ & $0.014^{\#}$ & 10.65 \\
\hline$\geq 1$ Hospita & zation & $14(15.4)$ & $7(7.7)$ & $4(4.4)$ & $3(3.3)$ & $0.010^{\#}$ & 11.452 \\
\hline$\geq 1$ Outpati & t visit & $74(81.3)$ & $44(48.4)$ & $49(54.4)$ & $50(55.6)$ & $0.000^{\# \# \#}$ & 24.264 \\
\hline$\geq 1$ Prescr & tion & $79(86.8)$ & $76(83.5)$ & $58(63.7)$ & $62(68.1)$ & $0.000^{\# \# \#}$ & 18.926 \\
\hline$\geq 1$ By own $n$ & dication & $12(13.2)$ & $12(13.2)$ & $6(6.6)$ & $7(7.7)$ & $.0296^{\#}$ & 3.700 \\
\hline$\geq 1$ Not to be & roceed & $9(9.9)$ & $10(11)$ & $10(11)$ & $8(8.8)$ & $.0331^{\#}$ & 0.954 \\
\hline
\end{tabular}

The frequency of bronchodilator during asthma attack-no. (\%)

\begin{tabular}{|c|c|c|c|c|c|}
\hline More than twice per day & $24(27.3)$ & $15(17)$ & $12(13.6)$ & $37(42)$ & \\
\hline Once to twice per day & $33(39.3)$ & $28(33.3)$ & $13(15.5)$ & $10(11.9)$ & \\
\hline $\begin{array}{c}\text { Twice to three times per } \\
\text { week }\end{array}$ & $9(47.4)$ & $3(15.8)$ & $6(31.6)$ & $1(5.3)$ & 63.257 \\
\hline Less than once per week & $15(26.3)$ & $13(22.8)$ & $19(33.3)$ & $10(17.5)$ & \\
\hline Never & $9(8.9)$ & $29(28.7)$ & $28(37.6)$ & $25(24.8)$ & \\
\hline
\end{tabular}

${ }^{\#} P<0.05 ;{ }^{*} P<0.01 ;{ }^{* \# *} P<0.001$. FEV1: Forced expiratory volume in one second; V1/FVC: Forced expirato-

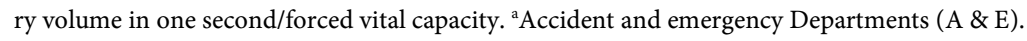

Table 4. The twenty-three symptoms of participants' self-evaluation.

\begin{tabular}{cccc}
\hline Symptom-no. (\%) & & & \\
1. wind intolerance & $14(16.3)$ & 13. lack of strength & $16(19.8)$ \\
2. susceptible cold & $13(20.6)$ & 14. lack of energy after asthma attack & $9(20.9)$ \\
3. sneeze Irunning nose before onset $16(22.5)$ & 15. poor appetite & $7(29.2)$ \\
4. onset during quarter & $6(8.0)$ & 16. abdomen fullness & $4(11.8)$ \\
5. rapid or difficult breathing & $33(26.4)$ & 17. sloopy stool & $4(10.0)$ \\
6. wake up by asthma symptoms & $25(29.4)$ & 18. diarrhea after intake of oil food & $2(6.3)$ \\
7. bluish complexion & $2(12.5)$ & 19. fear of cold & $13(17.6$ \\
8. spontaneous sweating & $8(19.5)$ & 20. soreness and weakness of waist and knees $15(20.3)$ \\
9. lassitude & $13(20.6)$ & 21. tinnitus & $10(20.4)$ \\
10. lack of speech & $7(28.0)$ & 22. frequent urination/night urination & $6(10.5)$ \\
11. decline in physical strength & $13(24.1)$ & 23. redness, hotness or anxiety & $7(16.7)$ \\
12. reduction of exercise & $2(6.9)$ & & \\
\hline
\end{tabular}


$0.001)$, and improvement in the $2^{\text {nd }}$ course and the $3^{\text {rd }}$ course improved similarly on the incidence of asthma attack in the past 12 months $(P>0.05)$ (Figure 2 , Table 5). This indicated the improvement in the $2^{\text {nd }}$ course and the $3^{\text {rd }}$ course were greater than the $1^{\text {st }}$ course.

\subsubsection{Days for Asthma Attacked in Past 12 Months}

Days for asthma attacked in past 12 months showed $106.49 \pm 142.83$ in baseline, and declined to $66.22 \pm 110.68$ in the $1^{\text {st }}$ course, $42.49 \pm 81.51$ in the $2^{\text {nd }}$ course, and $42.31 \pm 88.82$ in the $3^{\text {rd }}$ course, and there was improvement of days for asthma attacked among baseline, the $1^{\text {st }}$ course, the $2^{\text {nd }}$ course and the $3^{\text {rd }}$ course (All $P<0.05$ ) (Table 3 ). Compared with baseline, the $1^{\text {st }}$ course was decreased with the days of asthma attacked $(P<0.05)$; the $2^{\text {nd }}$ course was decreased sharply with the days of asthma attacked $(P<0.01)$; the value of the $3^{\text {rd }}$ course was decreased significantly $(P<0.001)$; the $3^{\text {rd }}$ course had the most improvement, but the improvements among the $1^{\text {st }}$ course, the $2^{\text {nd }}$ course and the $3^{\text {rd }}$ course were no statistical difference (All $P>0.05$ ), that means the $1^{\text {st }}$ course, the $2^{\text {nd }}$ course and the $3^{\text {rd }}$ course had experienced similar improvement on days for asthma attacked in the past 12 months, and the $3^{\text {rd }}$ course have a better improvement (Figure 3, Table 6).

\subsubsection{The Rate of Western Medicine Used during Asthma Attack}

After treatment, Western Medicine (bronchodilator) used during asthma attacked was: 1 ) decreased from $27.3 \%$ in baseline to $17 \%$ in the $1^{\text {st }}$ course and $13.6 \%$ in the $2^{\text {nd }}$ course, but increased to $42 \%$ in the $3^{\text {rd }}$ course; 2 ) decreased from $39.3 \%$ in baseline to $33.3 \%$ in the $1^{\text {st }}$ course, $15.5 \%$ in the $2^{\text {nd }}$ course and $11.9 \%$ in the $3^{\text {rd }}$ course once or twice per day; 3 ) decreased from $47.4 \%$ in baseline to $15.8 \%$ in the $1^{\text {st }}$ course, $31.6 \%$ in the $2^{\text {nd }}$ course and $5.3 \%$ in the $3^{\text {rd }}$ course

Table 5. The incidence of asthma attack in the last 12 months.

\begin{tabular}{ccccccc}
\hline Baseline \& & $\begin{array}{c}\text { Baseline \& } \\
\text { The } 1 \text { st course } \\
\text { course }\end{array}$ & $\begin{array}{c}\text { Baseline \& } \\
\text { The } 3^{\text {rd }} \text { course }\end{array}$ & $\begin{array}{c}\text { The 1st course } \\
\& \text { The 2nd } \\
\text { course }\end{array}$ & $\begin{array}{c}\text { The } 1 \text { st course } \\
\& \text { The } 3^{\text {rd }} \\
\text { course }\end{array}$ & $\begin{array}{c}\text { The 2nd } \\
\text { course \& The } \\
3^{\text {rd }} \text { course }\end{array}$ & \\
\hline$-2.714^{\mathrm{b}}$ & $-4.796^{\mathrm{b}}$ & $-3.838^{\mathrm{b}}$ & $-3.130^{\mathrm{b}}$ & $-1.732^{\mathrm{b}}$ & $-1.091^{\mathrm{c}}$ & $Z$ value \\
$0.007^{\# \#}$ & $0.000^{\# \#}$ & $0.000^{\# \# \#}$ & $0.002^{\# \#}$ & 0.083 & 0.275 & $P$ value \\
\hline
\end{tabular}

Noted: a. By Wilcoxon Signed Test 2 Related-Samples. b. Based on Rank. c. Based on Negative Rank. ${ }^{*} P<$ $0.05 ;{ }^{\# \#} P<0.01 ;{ }^{\# \# \#} P<0.001$.

Table 6. Days for asthma attack.

\begin{tabular}{|c|c|c|c|c|c|c|}
\hline $\begin{array}{c}\text { Baseline \& } \\
\text { The 1st course }\end{array}$ & $\begin{array}{c}\text { Baseline \& } \\
\text { The 2nd } \\
\text { course }\end{array}$ & $\begin{array}{c}\text { Baseline \& } \\
\text { The } 3^{\text {rd }} \text { course }\end{array}$ & $\begin{array}{c}\text { The 1st course } \\
\text { \& The } 2 \text { nd } \\
\text { course }\end{array}$ & $\begin{array}{c}\text { The 1st course } \\
\& \text { The } 3^{\text {rd }} \\
\text { course }\end{array}$ & $\begin{array}{c}\text { The } 2 \text { nd } \\
\text { course \& The } \\
3^{\text {rd }} \text { course }\end{array}$ & \\
\hline-2.15 & -2.95 & -3.77 & -.77 & -1.12 & -0.11 & $Z$ value \\
\hline $0.031^{\#}$ & $0.003^{\# \#}$ & $0.000^{\# \# \#}$ & 0.440 & 0.261 & 0.091 & $P$ value \\
\hline
\end{tabular}




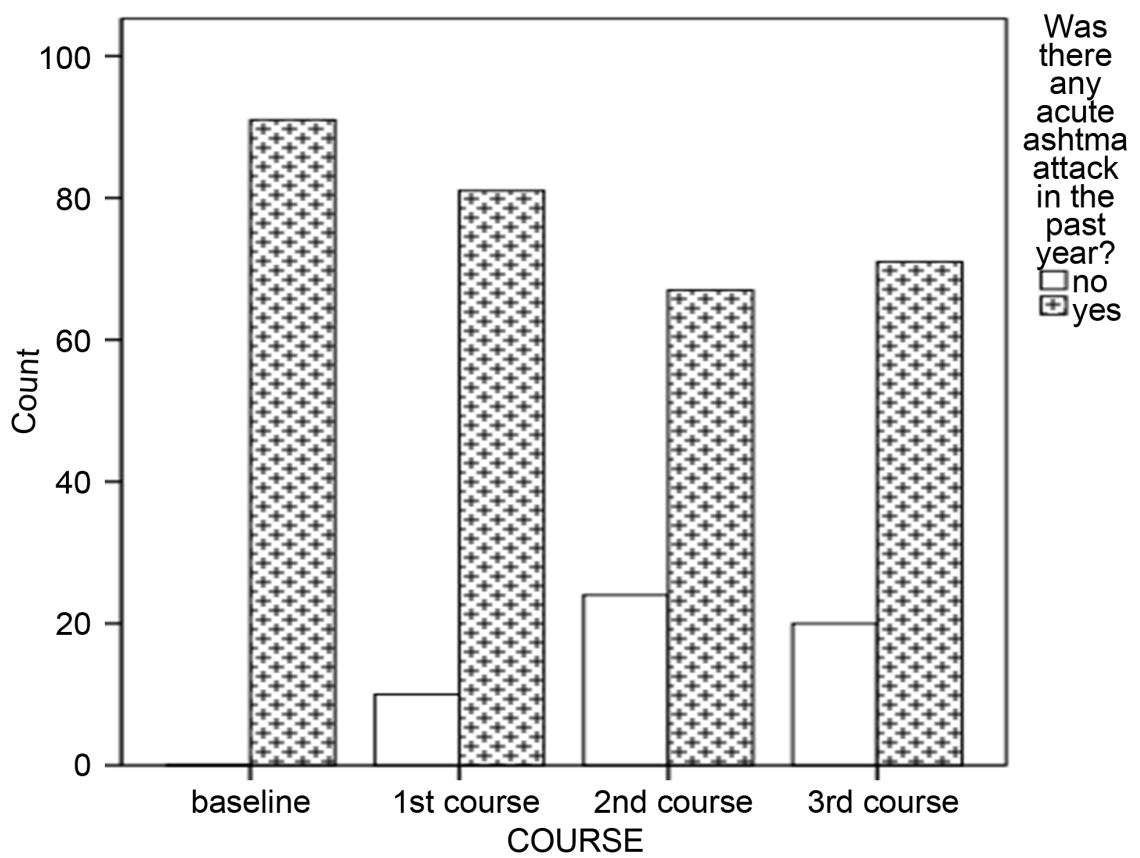

Figure 2. The incidence of asthma attack in the last 12 months.

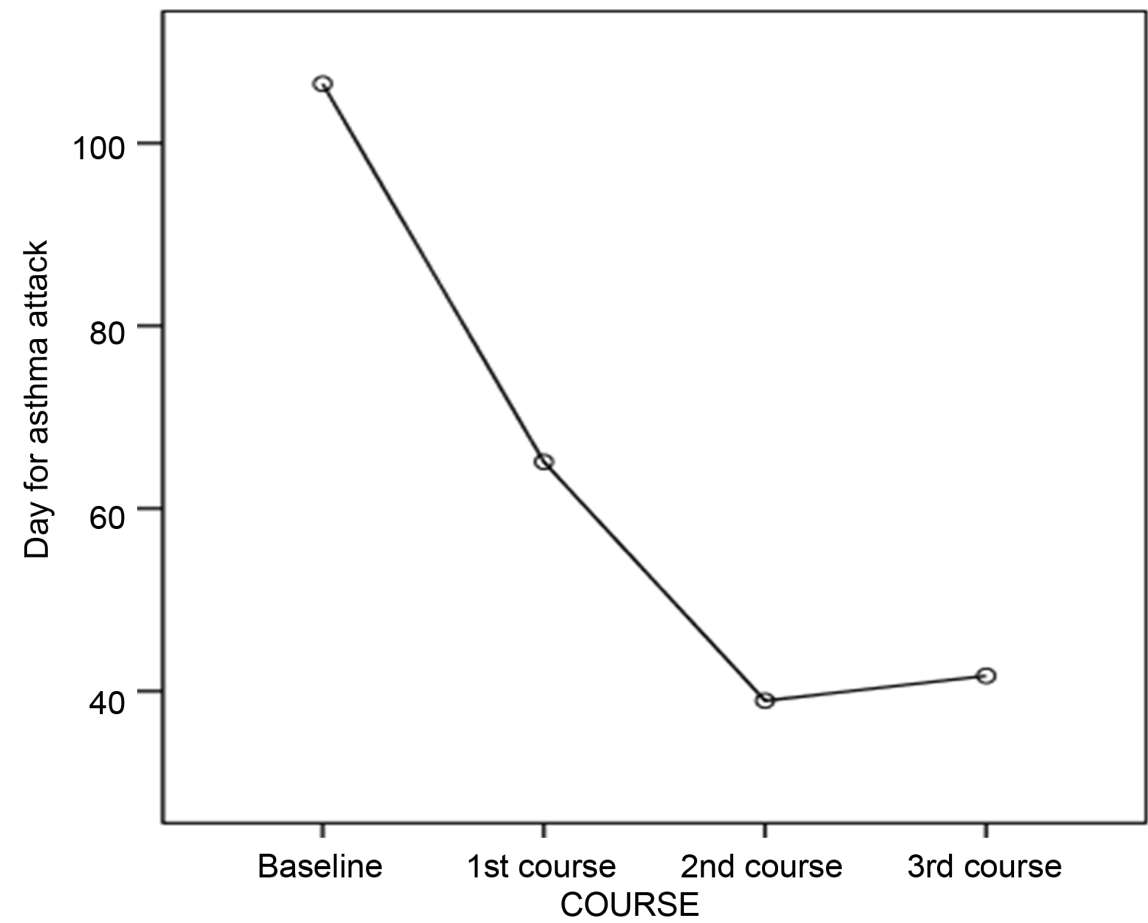

Figure 3. Days for asthma attacked in last 12 months.

twice or three times a week; 4) decreased from $26.3 \%$ in baseline to $22.8 \%$ in the $1^{\text {st }}$ course, $33.3 \%$ in the $2^{\text {nd }}$ course and $17.5 \%$ in the $3^{\text {rd }}$ course less than once per week; 5) increased from $8.9 \%$ in baseline to $28.9 \%$ in the $1^{\text {st }}$ course, $37.6 \%$ in the $2^{\text {nd }}$ course and $24.8 \%$ in the $3^{\text {rd }}$ course that never happened. There was significant decrease in the rate of western medicine used by asthma participants after treatment, and significant increase in the rate of western medicine never used by 
asthma participants after treatment $(P<0.05)$ (Table 3$)$. The $1^{\text {st }}$ course improved sharply $(P<0.01)$, the $2^{\text {nd }}$ course improved significantly $(P<0.001)$; the $3^{\text {rd }}$ course did not improved $(P>0.05)$, which indicated that the $1^{\text {st }}$ course and the $2^{\text {nd }}$ course both improved, but the $2^{\text {nd }}$ course improved better than the $1^{\text {st }}$ course $(P<0.05)$ (Figure 4, Table 7).

\subsubsection{The Rate of Processing Method during Tianjiu Therapy When Asthma Attacked}

Different processing method during Tianjiu therapy when asthma attacked included: 1) A \& E admitting during Tianjiu therapy was $22 \%$ at baseline, and decreased to $11 \%$ at the $1^{\text {st }}$ course and the $2^{\text {nd }}$ course, and $6.6 \%$ at the $3^{\text {rd }}$ course. Obviously, there was a great difference after any course of treatment, and the improvement have statistical difference $(P<0.05)$ (Table 3$)$. Average of admitting to A \& E was 2.69 at baseline, and decreased to 2.47 at the $1^{\text {st }}$ course and the $2^{\text {nd }}$ course, and decreased to 2.38 at the $3^{\text {rd }}$ course, the $3^{\text {rd }}$ course was sharply improved $(P<0.01)$, but there was no statistical difference between $1^{\text {st }}$ course and $3^{\text {rd }}$ course, $2^{\text {nd }}$ course and $3^{\text {rd }}$ course (All $P>0.05$ ) (Table 8 ), which indicated although there was no statistical difference among three courses on A \& E admitting during the past 12 months, there still had improvement at the $3^{\text {rd }}$ course (Figure 5).

2) The result showed significant statistical difference for admit to In-patient Hospital during Tianjiu therapy among the 4 time points $(P<0.05)$ (Table 3$)$.

Table 7. The rate of western medicine (bronchodilator) was used by asthma patients.

\begin{tabular}{ccccccc}
\hline $\begin{array}{c}\text { Baseline \& } \\
\text { The 1st course }\end{array}$ & $\begin{array}{c}\text { Baseline } \& \\
\text { The 2nd } \\
\text { course }\end{array}$ & $\begin{array}{c}\text { Baseline \& } \\
\text { The } 3^{\text {rd }} \text { course }\end{array}$ & $\begin{array}{c}\text { The } 1 \text { st course } \\
\text { \& The 2nd } \\
\text { course }\end{array}$ & $\begin{array}{c}\text { The } 1 \text { st course } \\
\& \text { The } 3^{\text {rd }} \\
\text { course }\end{array}$ & $\begin{array}{c}\text { The 2nd } \\
\text { course \& The } \\
3^{\text {rd }} \text { course }\end{array}$ \\
\hline$-3.232^{\mathrm{b}}$ & $-5.093^{\mathrm{b}}$ & $-1.722^{\mathrm{b}}$ & $-2.105^{\mathrm{b}}$ & $-1.378^{\mathrm{c}}$ & $-3.182^{\mathrm{c}}$ & $Z$ value \\
$0.001^{\#}$ & $0.000^{\# \#}$ & 0.085 & $0.035^{\#}$ & 0.168 & $0.001^{\# \#}$ & $P$ value \\
\hline
\end{tabular}

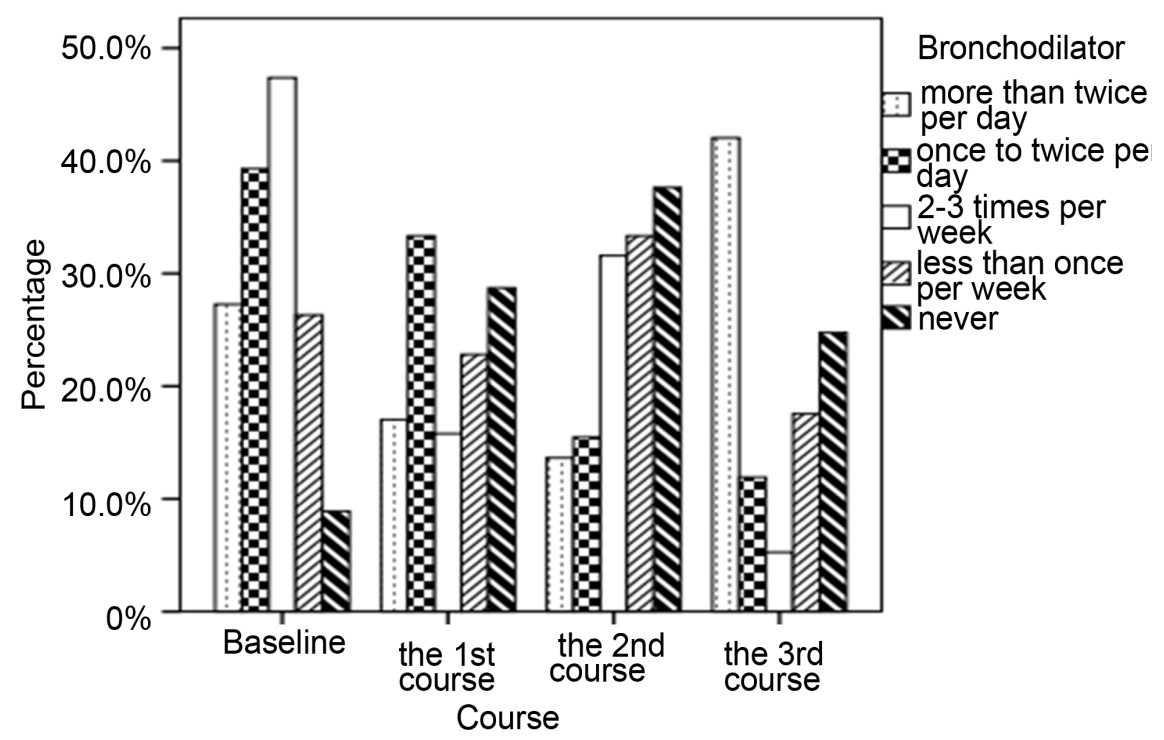

Figure 4. The rate of western medicine (bronchodilator) was used by asthma patients. 
The percentage was $15.4 \%$ at baseline, it was declined to $7.7 \%$ in the $1^{\text {st }}$ course $(P>0.05)$, and $4.4 \%$ in the $2^{\text {nd }}$ course $(P<0.001)$, and $3.3 \%$ in the $3^{\text {rd }}$ course $(P<$ $0.01)$. Although there was no statistical difference between $2^{\text {nd }}$ course and $3^{\text {rd }}$ course $(P>0.05)$, it still indicated that $2^{\text {nd }}$ course have a tendency of improving better than $3^{\text {rd }}$ course on admitting to In-patient Hospital during Tianjiu therapy on Sanfu days (Table 8, Figure 6).

3) The frequency of admitting to Integrated Chinese medicine \& Western Medicine Clinic was $81.3 \%$ at baseline, it declined to $48.4 \%$ at $1^{\text {st }}$ course, that

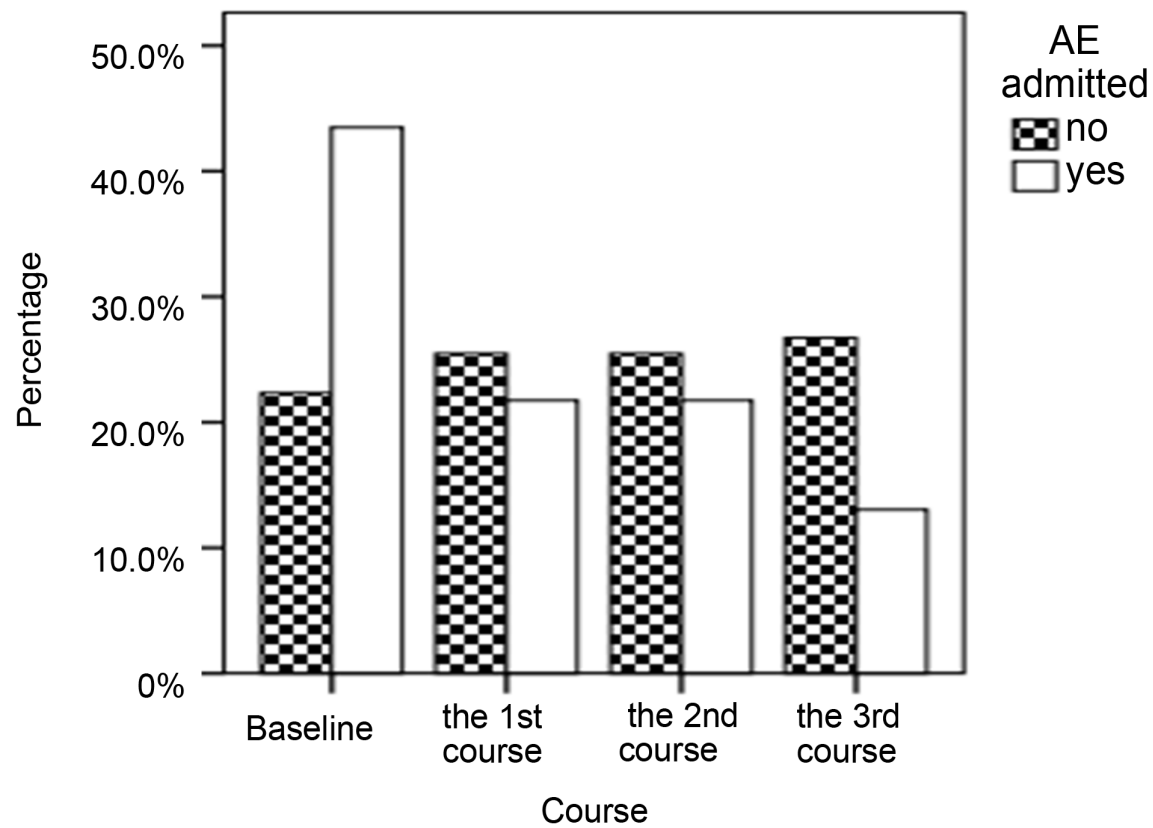

Figure 5. The frequency of admitting to A \& E.

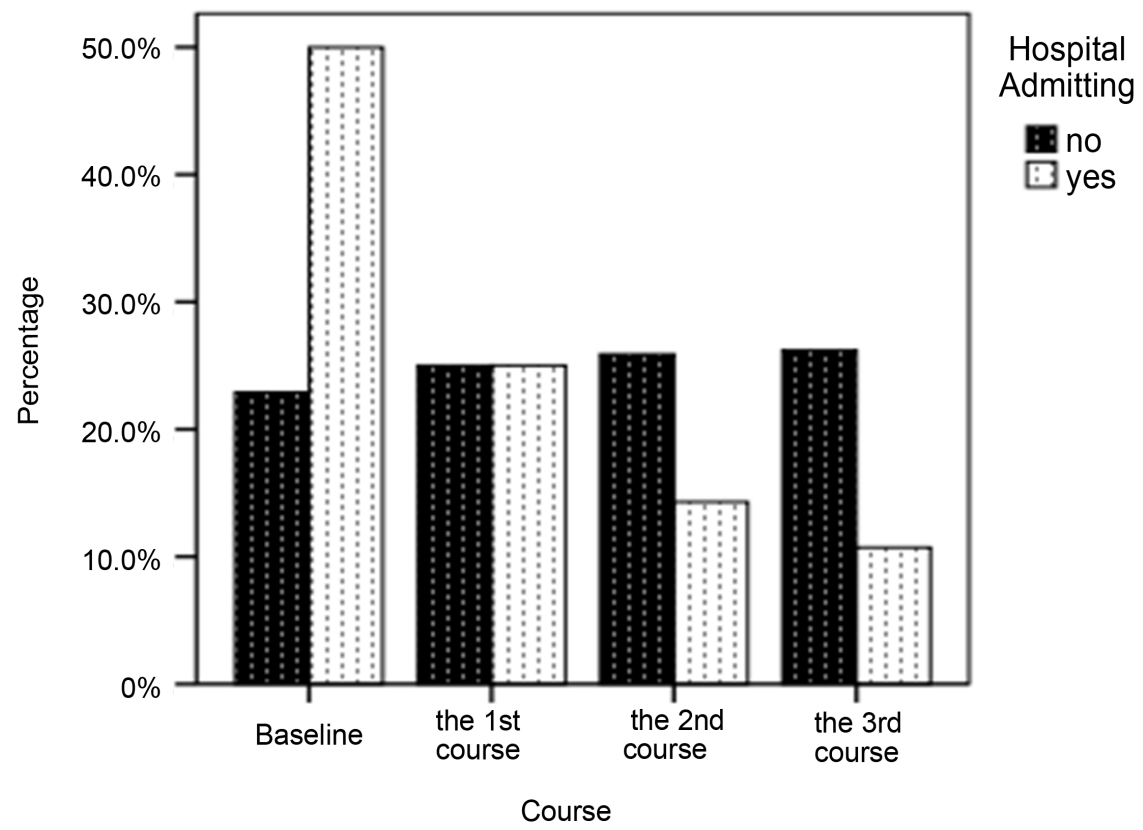

Figure 6. The frequency of admitting to hospital. 
means the $1^{\text {st }}$ course experienced significant improvement $(P<0.001)$; and $54.4 \%$ at $2^{\text {nd }}$ course, the $2^{\text {nd }}$ course experienced deeply improvement $(P<0.01)$, and $55.6 \%$ at the $3^{\text {rd }}$ course, the $3^{\text {rd }}$ course experienced significant improvement $(P<0.001)$ (Table 3$)$. But there was no tatistical difference mong $1^{\text {st }}$ course, $2^{\text {nd }}$ course and $3^{\text {rd }}$ course $(P>0.05)$. Results showed that 3 courses have similar improvements on frequency of admitting to Integrated Chinese medicine \& Western Medicine Clinic, and there was similar tendency of improvement between $1^{\text {st }}$ course and $3^{\text {rd }}$ course (Table 8, Figure 7).

4) The percentage of solving by persistent prescription when asthma attacked was $86.8 \%$ at baseline, it was declined to 83.5 at $1^{\text {st }}$ course $(P>0.05), 63.7 \%$ at the $2^{\text {nd }}$ course, it means $2^{\text {nd }}$ course experienced significant improvement $(P<0.001)$, and $68.1 \%$ at the $3^{\text {rd }}$ course, it means $3^{\text {rd }}$ course experienced sharply improvement $(\mathrm{P}<0.01)$, but there was no statistical difference between $2^{\text {nd }}$ course and $3^{\text {rd }}$ course on solving by persistent when asthma attack $(P>0.05)$ (Table 8$)$, which indicated that at $2^{\text {nd }}$ course have a better improvement on solving by persistent prescription when asthma attacked (Figure 8).

\subsubsection{Times of Different Processing Method during Tianjiu Therapy When Asthma Attacked}

1) Times for admitting to clinic was $18.88 \pm 48.404$ at baseline, it was decreased to $4.15 \pm 12.205$ at $1^{\text {st }}$ course $(P<0.001), 5.03 \pm 15.093$ at $2^{\text {nd }}$ course $(P<$ $0.001)$, and $0.57 \pm 0.519$ at $3^{\text {rd }}$ course $(P<0.001)$, which means that there was significant improvement on times for admitting to clinic (Table 8), and the improvements were similar among $1^{\text {st }}$ course, $2^{\text {nd }}$ course and $3^{\text {rd }}$ course (All $P>$ 0.05) (Table 8, Figure 9).

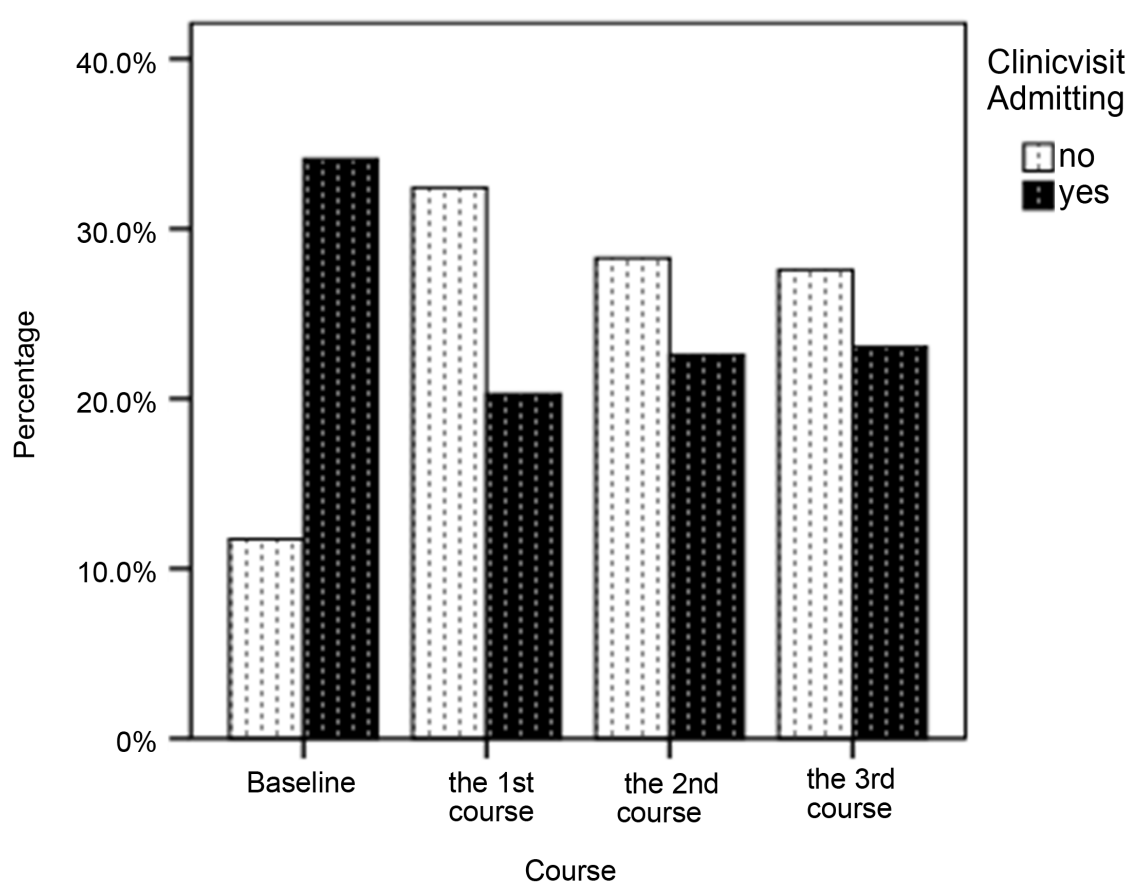

Figure 7. The frequency of admitting to Integrated Chinese Medicine \& Western Medicine Clinic. 
Table 8. Analyze health care of each two courses when asthma attacked.

\begin{tabular}{|c|c|c|c|c|c|c|c|}
\hline & $\begin{array}{l}\text { Baseline \& } \\
1^{\text {st }} \text { course }\end{array}$ & $\begin{array}{l}\text { Baseline \& } \\
2^{\text {nd }} \text { course }\end{array}$ & $\begin{array}{l}\text { Baseline \& } \\
3^{\text {rd }} \text { course }\end{array}$ & $\begin{array}{l}1^{\text {st }} \text { course } \& \\
2^{\text {nd }} \text { course }\end{array}$ & $\begin{array}{c}1^{\text {st }} \text { course } \& \\
3^{\text {rd }} \text { course }\end{array}$ & $\begin{array}{c}2^{\text {nd }} \text { course \& } \\
3^{\text {rd }} \text { course }\end{array}$ & \\
\hline Admit to A & $-2.041^{\mathrm{d}}$ & $-2.041^{\mathrm{d}}$ & $-2.985^{\mathrm{b}}$ & $0.000^{c}$ & $-1.069^{d}$ & $-1.155^{\mathrm{b}}$ & $Z$ value \\
\hline \& E & 0.41 & 0.41 & $0.003^{\# \#}$ & 1.000 & 0.285 & 0.248 & $P$ value \\
\hline \multirow{2}{*}{$\begin{array}{l}\text { Admit to } \\
\text { hospital }\end{array}$} & $-1.698^{\mathrm{b}}$ & $-7.500^{c}$ & $-3.051^{b}$ & $-1.000^{\mathrm{b}}$ & $-1.265^{\mathrm{b}}$ & $-0.447^{\mathrm{b}}$ & $Z$ value \\
\hline & 0.090 & $0.000^{\# \# \#}$ & $0.002^{\# \#}$ & 0.317 & 0.206 & 0.655 & $P$ value \\
\hline \multirow{2}{*}{$\begin{array}{l}\text { Admit to } \\
\text { clinic }\end{array}$} & $-4.423^{b}$ & $-3.429^{\mathrm{b}}$ & $-3.773^{b}$ & $-1.121^{\mathrm{c}}$ & $-1.333^{c}$ & $-0.169^{c}$ & $Z$ value \\
\hline & $0.000^{\# \# \#}$ & $0.001^{\# \#}$ & $0.000^{\# \# \#}$ & 0.262 & 0.182 & 0.886 & $P$ value \\
\hline \multirow{2}{*}{$\begin{array}{l}\text { Solve by } \\
\text { persistent } \\
\text { medication }\end{array}$} & $-0.600^{\mathrm{b}}$ & $-3.550^{\mathrm{b}}$ & $-3.053^{\mathrm{b}}$ & $-3.182^{\mathrm{b}}$ & $-2.475^{\mathrm{b}}$ & $-0.649^{c}$ & $Z$ value \\
\hline & 0.549 & $0.000^{\# \# \#}$ & $0.002^{\# \#}$ & $0.001^{\# \#}$ & $0.013^{\#}$ & 0.516 & $P$ value \\
\hline \multirow{2}{*}{$\begin{array}{l}\text { Times of } \\
\text { admitting to } \\
\text { clinic }\end{array}$} & $-3.781^{b}$ & $-4.158^{\mathrm{b}}$ & $-4.211^{\mathrm{b}}$ & $-0.028^{\mathrm{b}}$ & $-0.543^{\mathrm{c}}$ & $-1.432^{\mathrm{c}}$ & $Z$ value \\
\hline & 0.000 & 0.000 & 0.000 & 0.978 & 0.587 & 0.152 & $P$ value \\
\hline \multirow{2}{*}{$\begin{array}{l}\text { Times of } \\
\text { solving by } \\
\text { persistent } \\
\text { medicine }\end{array}$} & $-4.526^{\mathrm{b}}$ & $-4.435^{\mathrm{b}}$ & $-5.162^{\mathrm{b}}$ & $-0.304^{\mathrm{b}}$ & $-4.435^{\mathrm{b}}$ & $-0.65^{\mathrm{c}}$ & $Z$ value \\
\hline & 0.000 & 0.000 & 0.000 & 0.761 & 0.000 & 0.948 & $P$ value \\
\hline \multirow{2}{*}{$\begin{array}{l}\text { Times by } \\
\text { own medica- } \\
\text { tion }\end{array}$} & $-3.141^{\mathrm{b}}$ & $-3.935^{\mathrm{b}}$ & $-4.226^{\mathrm{b}}$ & $-8.69^{b}$ & $-3.935^{\mathrm{b}}$ & $-0.347^{\mathrm{b}}$ & $Z$ value \\
\hline & 0.001 & 0.000 & 0.000 & 0.385 & 0.000 & 0.729 & $P$ value \\
\hline
\end{tabular}

Noted: a. Wilcoxon Signed-rank test. b. based on rank. c. based on negative rank.

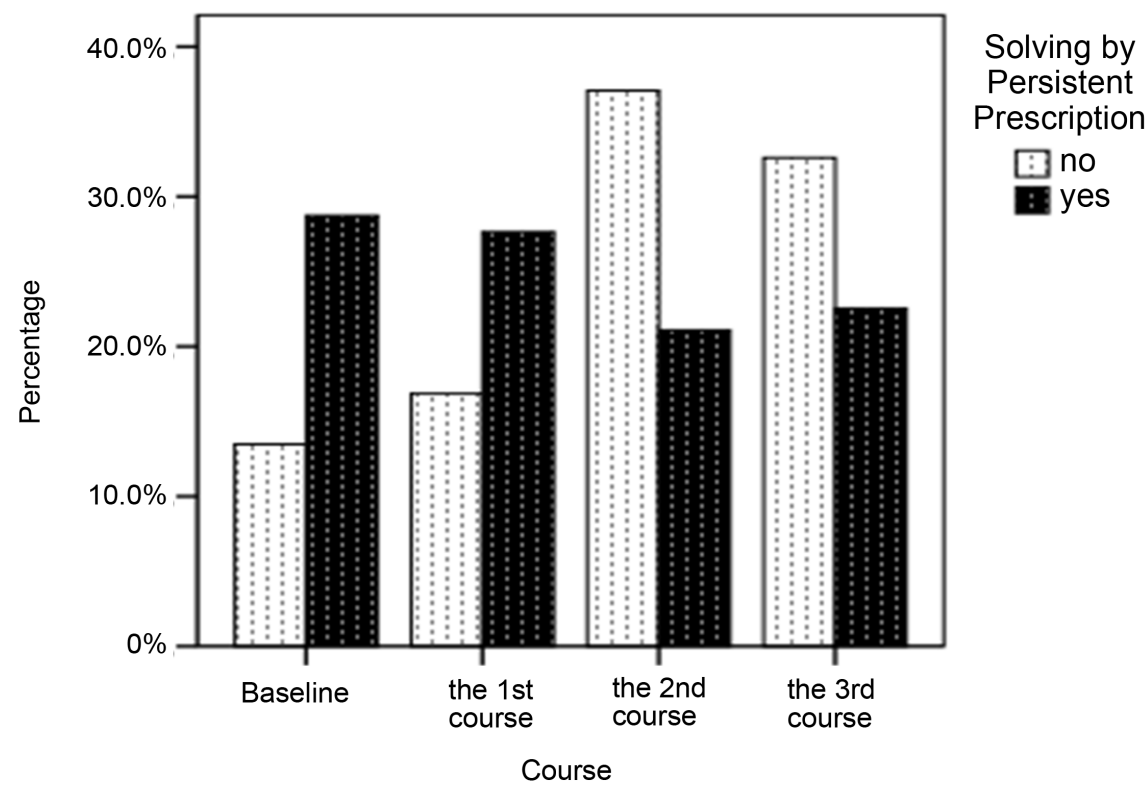

Figure 8. The frequency of solving by persistent prescription.

2) Times for persistent prescription when asthma attacked was $130.03 \pm$ 93.349 at baseline, it was decreased to $47.63 \pm 103.014$ at $1^{\text {st }}$ course, $64.08 \pm$ 175.212 at $2^{\text {nd }}$ course, and $16.86 \pm 93.963$ at $3^{\text {rd }}$ course, which means that there were significant statistical differences (All $P<0.05$ ) (Table 9), but without any 


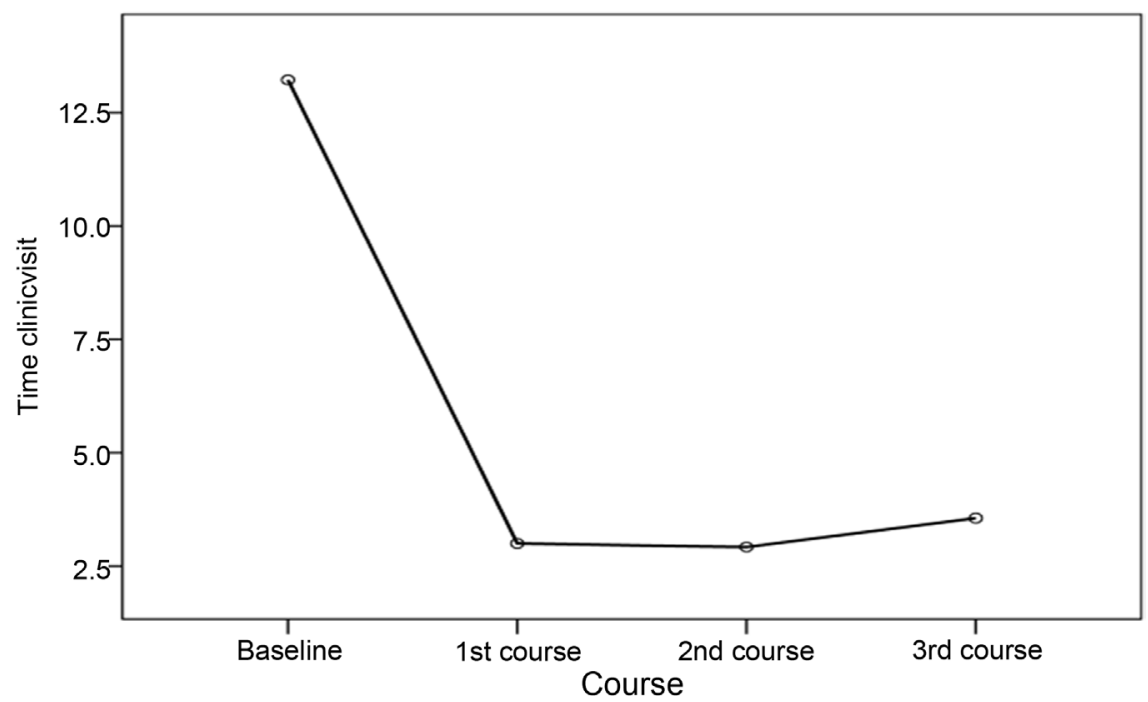

Figure 9. Times for admitting to hospital.

Table 9. Analyze health care of all courses when asthma attacked.

\begin{tabular}{cccccc}
\hline $\begin{array}{c}\text { Variable } \\
\text { (Average/Mean } \pm \mathrm{SD})\end{array}$ & baseline & The $1^{\text {st }}$ course & The $2^{\text {nd }}$ course & The $3^{\text {rd }}$ course & $P$ value \\
\hline Times to A \& E & $0.51 \pm 1.23$ & $0.18 \pm 0.53$ & $1.24 \pm 10.38$ & $0.07 \pm 0.25$ & 0.339 \\
Times to hospital & $1.41 \pm 10.40$ & $0.11 \pm 0.41$ & $0.09 \pm 0.49$ & $0.04 \pm 0.21$ & 0.227 \\
Times to clinic & $18.88 \pm 48.40$ & $4.15 \pm 12.20$ & $5.03 \pm 15.09$ & $0.57 \pm 0.52$ & $0.002^{\# \#}$ \\
Times to persistent & $130.03 \pm 93.35$ & $47.63 \pm 103.01$ & $64.08 \pm 175.21$ & $16.86 \pm 93.95$ & $0.001^{\# \#}$ \\
Times by own medicine & $20.57 \pm 39.46$ & $4.63 \pm 20.37$ & $2.40 \pm 14.59$ & $1.42 \pm 10.48$ & $0.000^{\# \#}$ \\
Times of not proceed & $9.84 \pm 43.96$ & $14.60 \pm 115.44$ & $3.31 \pm 19.46$ & $1.29 \pm 10.38$ & 0.386 \\
\hline
\end{tabular}

statistical difference among $1^{\text {st }}$ course, $2^{\text {nd }}$ course and $3^{\text {rd }}$ course $(P>0.05)$ (Table 9), which means the $1^{\text {st }}$ course, the $2^{\text {nd }}$ course, the $3^{\text {rd }}$ course experienced similar improvements on times for persistent prescription after Tianjiu therapy on Sanfu days (Figure 10).

3) Times of solving by own medication was $20.57 \pm 39.456$ at baseline, it was decreased to $4.63 \pm 20.372$ at $1^{\text {st }}$ course $(P<0.01)$, which indicated that the $1^{\text {st }}$ course experienced sharply improvement; $2.40 \pm 14.594$ at $2^{\text {nd }}$ course $(P<0.001)$, and $1.42 \pm 10.483$ at $3^{\text {rd }}$ course $(P<0.001)$, which indicated that $2^{\text {nd }}$ course and $3^{\text {rd }}$ course experienced significant improvement (Table 9), but there were no statistical difference between $2^{\text {nd }}$ course and $3^{\text {rd }}$ course $(P>0.05)$ (Table 9$)$, that means $2^{\text {nd }}$ course and $3^{\text {rd }}$ course experienced similar improvement on the times of solving by own medication (Figure 11).

\subsubsection{The Percentage of Treatments Received When Asthma Attacked}

1) The rate of receiving Chinese Herbal Medicine when asthma attacked was $34 \%$ at baseline, and it was decreased to $24.2 \%$ at $1^{\text {st }}$ course $(P>0.05), 15.2 \%$ at $2^{\text {nd }}$ course $(P<0.001)$, and $23.1 \%$ at $3^{\text {rd }}$ course $(P<0.01)$ (Table 10 , Figure 13$)$. Which indicated that $1^{\text {st }}$ course had no improvement compared with baseline, 


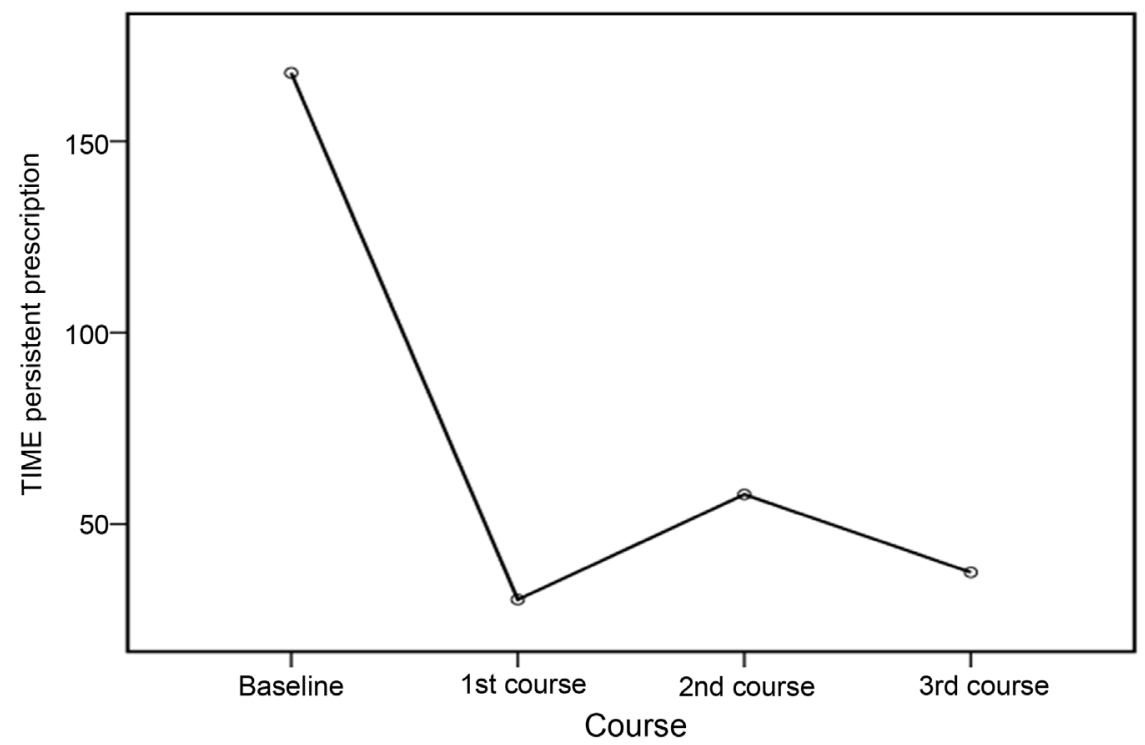

Figure 10. Times for persistent prescription.

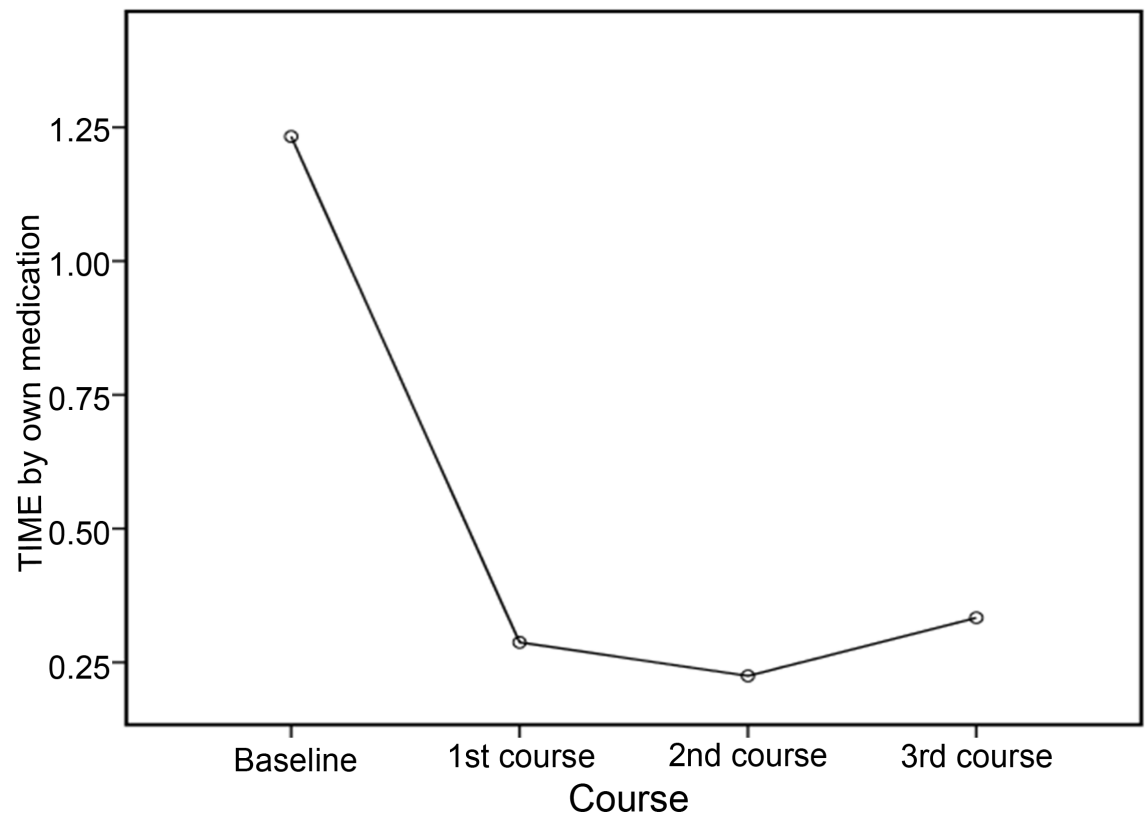

Figure 11. Times for times by own medication.

the $2^{\text {nd }}$ course experienced sharply improvement, and $3^{\text {rd }}$ course experienced significant improvement compared with baseline, but there was no statistical difference between $2^{\text {nd }}$ course and $3^{\text {rd }}$ course $(P>0.05)$ (Table 10), which means that the $2^{\text {nd }}$ course and the $3^{\text {rd }}$ course have experienced similar significant improvement of the rate of receiving Chinese Herbal Medicine when asthma attacked, but $2^{\text {nd }}$ course experienced a better improvement tendency than $3^{\text {rd }}$ course (Figure 12).

2) The rate of other treatments was $8.8 \%$ at baseline, and it was increased to $30.8 \%$ at $1^{\text {st }}$ course $(P<0.01), 39.1 \%$ at $2^{\text {nd }}$ course $(P<0.001)$, and $16.5 \%$ at $3^{\text {rd }}$ course $(P>0.05)$ (Table 10), which indicated participants increased to accept 


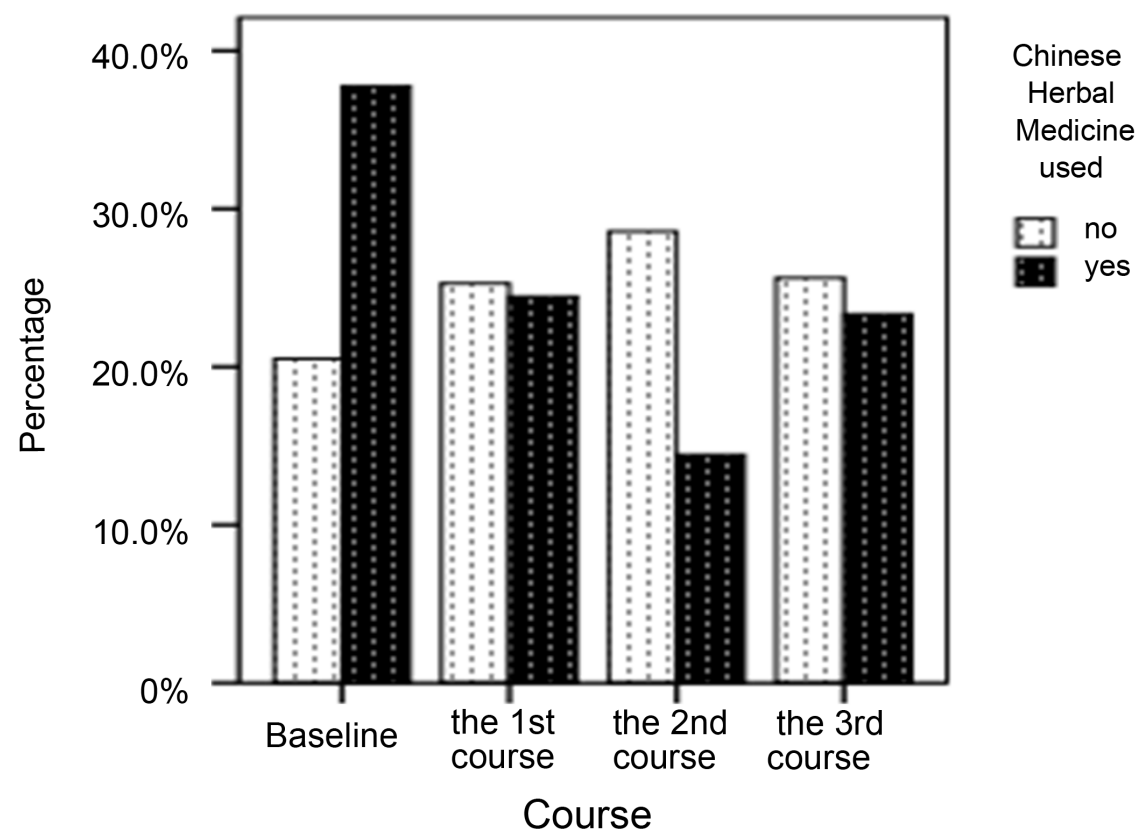

Figure 12. The rate of Chinese Herb Medicine.

Table 10. The percentage of treatments received other than Western Medicine for asthma.

\begin{tabular}{|c|c|c|c|c|c|c|}
\hline -no. (\%) & Baseline & $\begin{array}{l}\text { The } 1^{\text {st }} \\
\text { course }\end{array}$ & $\begin{array}{l}\text { The } 2^{\text {nd }} \\
\text { course }\end{array}$ & $\begin{array}{l}\text { The } 3^{\text {rd }} \\
\text { course }\end{array}$ & $P$ value & $\mathrm{X}^{2}$ \\
\hline $\begin{array}{l}\text { Any treatments other } \\
\text { than Western Medicine }\end{array}$ & $42(46.2)$ & $38(41.8)$ & $38(41.3)$ & $30(33)$ & 0.305 & 3.62 \\
\hline Chinese Herb Medicine & $34(37.4)$ & $22(24.2)$ & $14(15.2)$ & $21(23.1)$ & $0.003^{\# \#}$ & 13.69 \\
\hline $\begin{array}{l}\text { Acupuncture \& } \\
\text { Moxibustion }\end{array}$ & $14(15.4)$ & $9(9.9)$ & $7(7.6)$ & $11(12.1)$ & 0.385 & 3.05 \\
\hline Others & $8(8.8)$ & $28(30.8)$ & $36(39.1)$ & $15(16.5)$ & $0.000^{\# \# \#}$ & 24.48 \\
\hline
\end{tabular}

other treatment at $1^{\text {st }}$ course and $2^{\text {nd }}$ course, there was no statistical difference at $3^{\text {rd }}$ course compared with baseline $(P>0.05)$ (Table 10, Table 11, Figure 13).

\subsubsection{The Percentage of Asthma under Controlled}

The percentage of asthma participants under controlled was $11.9 \%$ at baseline, it was increased to $18.1 \%$ at $1^{\text {st }}$ course $(P>0.05), 35.2 \%$ at $2^{\text {nd }}$ course $(P<0.001)$, and $34.8 \%$ at $3^{\text {rd }}$ course $(P<0.001)$ (Table 12). There were significant statistical differences between $1^{\text {st }}$ course and $2^{\text {nd }}$ course, $1^{\text {st }}$ course and $3^{\text {rd }}$ course (All $P<$ $0.05)$, There was no significant statistical difference between $2^{\text {nd }}$ course and $3^{\text {rd }}$ course $(P>0.05)$ (Table 12, Table13). The results indicated that $2^{\text {nd }}$ course and $3^{\text {rd }}$ course experienced similarly percentages of asthma under controlled (Figure $14)$.

\subsubsection{The Percentage of Asthma Have No Improvement after Tianjiu Therapy}

The percentage of asthma participants experienced no improvement was 38.6\% 


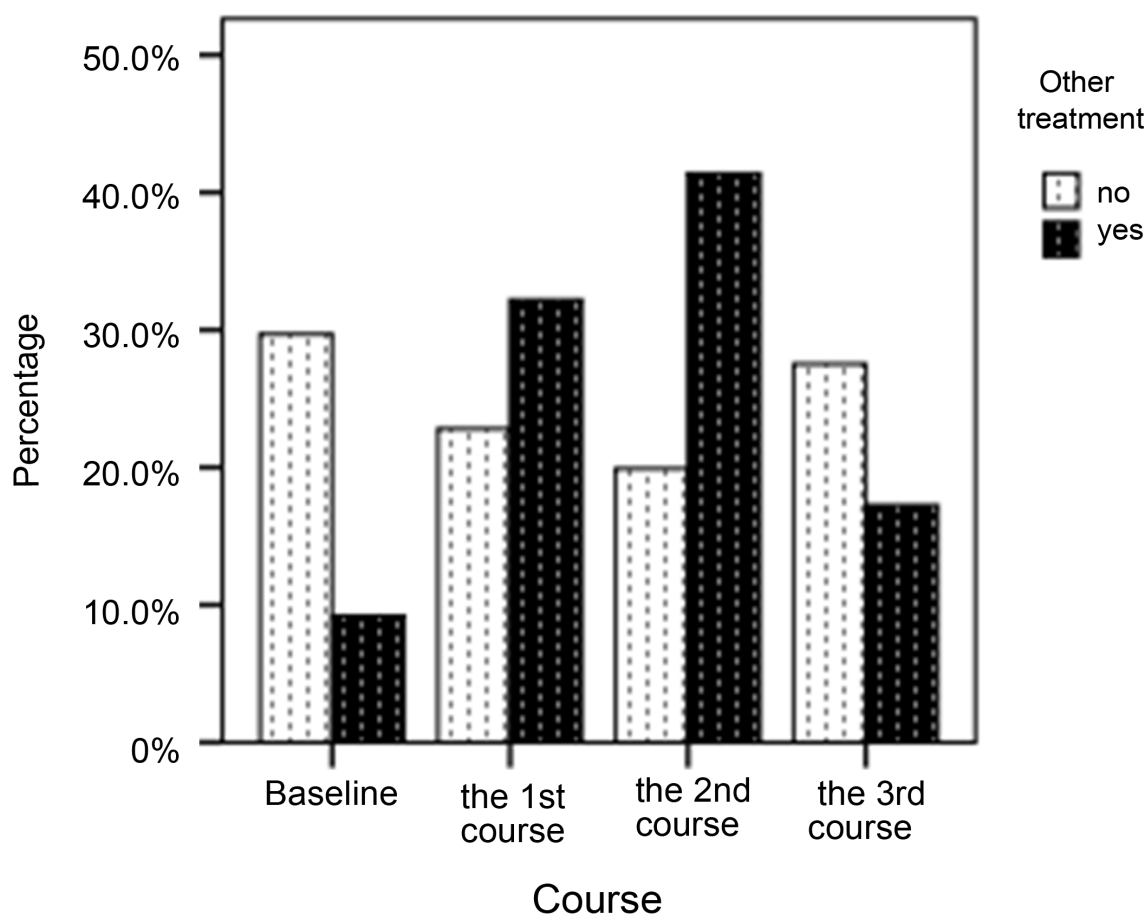

Figure 13. Other treatments than western medicine and Chinese Medicine and acupuncture \& moxibustion.

Table 11. Treatments received when asthma attack by Wilcoxon Signed Test 2 Related-Samples.

\begin{tabular}{|c|c|c|c|c|c|c|c|}
\hline & $\begin{array}{c}\text { Baseline } 8 \\
\text { The } 1^{\text {st }} \\
\text { course }\end{array}$ & $\begin{array}{l}\text { Baseline \& } \\
\text { The } 2^{\text {nd }} \\
\text { course }\end{array}$ & $\begin{array}{c}\text { Baseline \& } \\
\text { The } 3^{\text {rd }} \\
\text { course }\end{array}$ & $\begin{array}{l}\text { The } 1^{\text {st }} \text { course \& } \\
\text { The } 2^{\text {nd }} \text { course }\end{array}$ & $\begin{array}{c}\text { The } 1^{\text {st }} \text { course } \\
\& \text { The } 3^{\text {rd }} \\
\text { course }\end{array}$ & $\begin{array}{l}\text { The } 2^{\text {nd }} \\
\text { course } \& \\
3^{\text {rd }} \text { course }\end{array}$ & \\
\hline $\begin{array}{l}\text { Chinese } \\
\text { herbal }\end{array}$ & $-2.175^{\mathrm{b}}$ & $-3.781^{\mathrm{b}}$ & $-2.694^{\mathrm{b}}$ & $-2.065^{b}$ & $-1.92^{\mathrm{b}}$ & $-1.886^{\mathrm{c}}$ & $Z$ value \\
\hline Medicine & 0.13 & $0.000^{\# \# \#}$ & $0.007^{\# \#}$ & $0.039^{\#}$ & 0.847 & 0.059 & $P$ value \\
\hline Other & $-3.182^{c}$ & $-3.920^{c}$ & $-8.16^{\mathrm{c}}$ & $-1.155^{\mathrm{c}}$ & $-2.030^{\mathrm{b}}$ & $-3.550^{\mathrm{b}}$ & $Z$ value \\
\hline treatments & $0.001^{\# \#}$ & $0.000^{\# \# \#}$ & 0.414 & 0.248 & $0.040^{\#}$ & $0.000^{\# \# \#}$ & $P$ value \\
\hline
\end{tabular}

Noted: a. By Wilcoxon Signed Test 2 Related-Samples. b. based on rank. c. based on negative rank.

Table 12. The percentage of asthma is under controlled and no improvement of 3 courses and baseline.

\begin{tabular}{ccccccc}
\hline -no. (\%) & Baseline & $\begin{array}{c}\text { The } 1^{\text {st }} \\
\text { course }\end{array}$ & $\begin{array}{c}\text { The } 2^{\text {nd }} \\
\text { course }\end{array}$ & The $3^{\text {rd }}$ course & $P_{\text {value }}$ & $\mathrm{X}^{2}$ \\
\hline $\begin{array}{c}\text { Asthma is under } \\
\text { controlled }\end{array}$ & $25(11.9)$ & $38(18.1)$ & $74(35.2)$ & $73(34.8)$ & 0.000 & 83.245 \\
$\begin{array}{c}\text { No improvement } \\
\text { imp }\end{array}$ & $27(38.6)$ & $19(27.1)$ & $11(15.7)$ & $13(18.6)$ & 0.012 & 10.966 \\
\hline
\end{tabular}

at baseline, it was decreased to $21.7 \%$ at $1^{\text {st }}$ course, $15.7 \%$ at $2^{\text {nd }}$ course, and $18.6 \%$ at $3^{\text {rd }}$ course, and the decline of four time points has a statistical difference $(P<0.05)$ (Table 13). There was no improvement compare $1^{\text {st }}$ course with baseline $(P>0.05)$. There were significant statistical difference on improvement between $2^{\text {nd }}$ course and baseline, $3^{\text {rd }}$ course and baseline $(P<0.01)$, There was no 


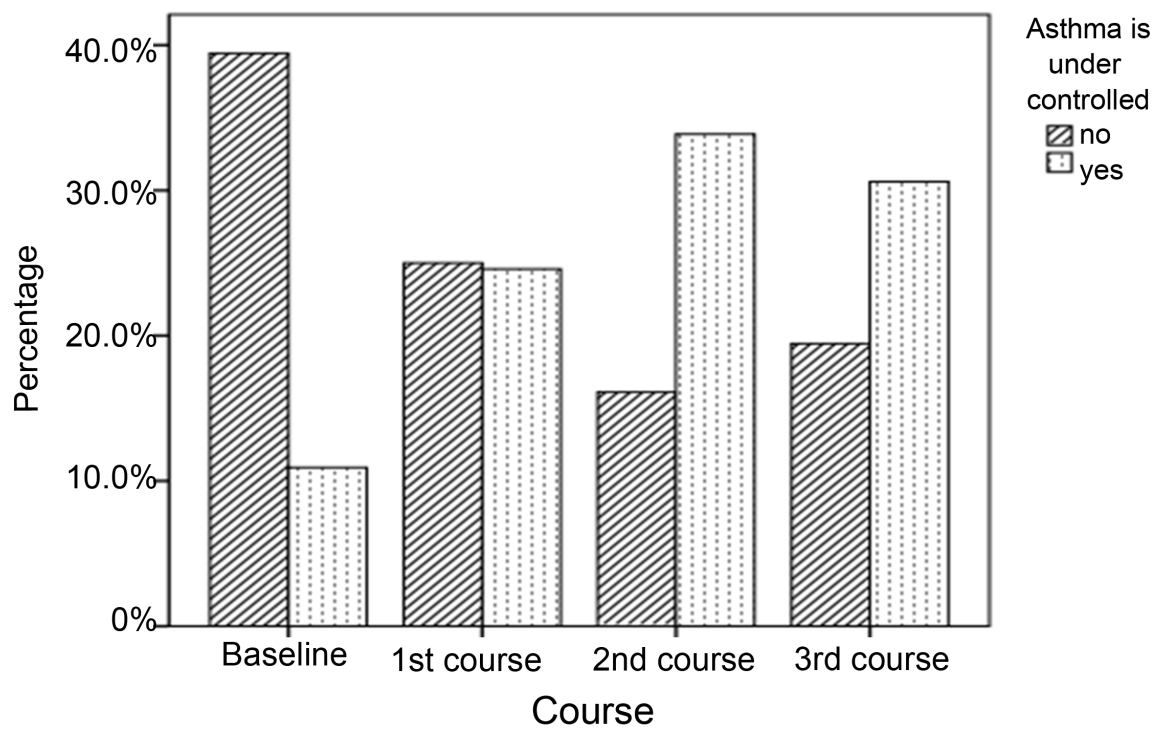

Figure 14. The percentage of asthma under controlled.

Table 13. The percentage of asthma is under controlled by Wilcoxon Signed Test 2 Related-Samples.

\begin{tabular}{|c|c|c|c|c|c|c|c|}
\hline & $\begin{array}{l}\text { Baseline } \\
\& \text { the } \\
1^{\text {st }} \text { course }\end{array}$ & $\begin{array}{l}\text { Baseline } \\
\& \text { the } \\
2^{\text {nd }} \text { course }\end{array}$ & $\begin{array}{l}\text { Baseline } \\
\& \text { the } 3^{\text {rd }} \\
\text { course }\end{array}$ & $\begin{array}{c}\text { The } 1^{\text {st }} \\
\text { course \& the } \\
2^{\text {nd }} \text { course }\end{array}$ & $\begin{array}{c}\text { The } 1^{\text {st }} \\
\text { course \& the } \\
3^{\text {rd }} \text { course }\end{array}$ & $\begin{array}{l}\text { The } 2^{\text {nd }} \text { course } \\
\& \text { the } 3^{\text {rd }} \text { course }\end{array}$ & \\
\hline \multirow{2}{*}{$\begin{array}{c}\text { No } \\
\text { improvement }\end{array}$} & $-1.414^{\mathrm{b}}$ & $-2.828^{\mathrm{b}}$ & $-2.858^{\mathrm{b}}$ & $-1.633^{b}$ & $-1.279^{\mathrm{b}}$ & $-4.71^{\mathrm{c}}$ & $P$ value \\
\hline & 0.157 & 0.005 & 0.004 & 0.102 & 0.201 & 0.637 & $Z$ value \\
\hline \multirow{2}{*}{$\begin{array}{c}\text { Under } \\
\text { controlled }\end{array}$} & $-1.857^{b}$ & $-6.607^{b}$ & $-6.532^{\mathrm{b}}$ & $-5.427^{b}$ & $-5.105^{b}$ & $-0.200^{c}$ & $P$ value \\
\hline & 0.063 & 0.000 & 0.000 & 0.000 & 0.000 & 0.841 & $Z$ value \\
\hline
\end{tabular}

Noted: a. Wilcoxon Signed-rank test. b. based on rank. c. based on negative rank.

improvement compare $2^{\text {nd }}$ course with $3^{\text {rd }}$ course $(P>0.05)$ (Table 12, Table 13). The results indicated that the percentage of asthma have no improvement in the $2^{\text {nd }}$ course and the $3^{\text {rd }}$ course (Figure 15).

\subsubsection{The rate of Twenty-three Symptoms during Tianjiu Therapy}

1) Percentage of rapid or difficult breathing was $32.4 \%$ at baseline, it was decreased to $18.8 \%$ at $1^{\text {st }}$ course, $25.8 \%$ at $2^{\text {nd }}$ course, $23.0 \%$ at $3^{\text {rd }}$ course, there were statistical difference among the baseline and the 3 courses $(P<0.05)$ (Table 14). $1^{\text {st }}$ course improved significantly $(P<0.001), 2^{\text {nd }}$ course sharply $(P<0.01)$, and $3^{\text {rd }}$ course improved $(P<0.05)$, the $2^{\text {nd }}$ course and the $3^{\text {rd }}$ course similar improvement in the statistical $(P>0.05)$, that was to say the $1^{\text {st }}$ course has best improvement in the percentage of rapid or difficult breathing during Tianjiu Therapy (Table 15, Figure 16).

2) The percentage of wake up by asthma symptoms was $39.5 \%$ at baseline, it was decreased to $17.5 \%$ at $1^{\text {st }}$ course, $22.0 \%$ at $2^{\text {nd }}$ course, $20.9 \%$ at $3^{\text {rd }}$ course, the proportions of 3 courses after treatment reduced significantly compared with baseline $(P<0.05)$ (Table 14$)$. The percentages of the $1^{\text {st }}$ course, the $2^{\text {nd }}$ course, and the $3^{\text {rd }}$ course were all improved significantly with baseline (All $P<0.001$ ), 
Table 14. The participants' symptoms scale of 3 courses.

\begin{tabular}{|c|c|c|c|c|c|}
\hline Symptoms scale & Baseline & $\begin{array}{l}\text { The } 1^{\text {st }} \\
\text { course }\end{array}$ & $\begin{array}{l}\text { The } 2^{\text {nd }} \\
\text { course }\end{array}$ & $\begin{array}{l}\text { The } 3^{\text {rd }} \\
\text { course }\end{array}$ & $P$ value \\
\hline \multicolumn{6}{|c|}{ Detail symptoms—no. (\%) } \\
\hline 1 Wind intolerance & $38(25.3)$ & $29(19.3)$ & $41(27.3)$ & $42(28.0)$ & 0.19 \\
\hline 2 Susceptible cold & $43(31.9)$ & $26(19.5)$ & $32(23.7)$ & $34(25.2)$ & 0.072 \\
\hline 3 Sneezelrunning nose before onset & $47(26.3)$ & $38(21.2)$ & $42(23.5)$ & $52(29.1)$ & 0.182 \\
\hline 4 Onset during quarter & $58(25.6)$ & $49(21.6)$ & $64(28.2)$ & $56(24.7)$ & 0.146 \\
\hline 5 Rapid or difficult breathing & $69(32.4)$ & $40(18.8)$ & $55(25.8)$ & $49(23.0)$ & 0.000 \\
\hline 6 Wake up by asthma symptoms & $70(39.5)$ & $31(17.5)$ & $39(22.0)$ & $37(20.9)$ & 0.000 \\
\hline 7 Bluish complexion & $13(31.0)$ & $7(16.7)$ & $9(21.4)$ & $13(31.0)$ & 0.406 \\
\hline 8 Spontaneous sweating & $27(32.9)$ & $10(12.2)$ & $23(28.0)$ & $22(26.8)$ & 0.017 \\
\hline 9 Lassitude & $53(38.7)$ & $25(18.2)$ & $26(19.0)$ & $33(24.1)$ & 0.000 \\
\hline 10 Lack of speech & $27(34.2)$ & $16(20.3)$ & $18(22.8)$ & $18(22.8)$ & 0.195 \\
\hline 11 Decline in physical strength & $39(29.8)$ & $26(19.8)$ & $29(22.1)$ & $37(28.2)$ & 0.135 \\
\hline 12 Reduction of exercise & $19(26.0)$ & $8(11.0)$ & $24(32.9)$ & $22(30.1)$ & 0.015 \\
\hline 13 Lack of strength & $58(33.7)$ & $37(21.5)$ & $36(20.9)$ & $41(23.8)$ & 0.003 \\
\hline 14 Lack of energy after asthma attack & $25(26.9)$ & $15(16.1)$ & $26(28.0)$ & $27(29.0)$ & 0.147 \\
\hline 15 Poor appetite & $15(29.4)$ & $10(19.6)$ & $13(25.5)$ & $13(25.5)$ & 0.762 \\
\hline 16 Abdomen fullness & $21(24.1)$ & $16(18.4)$ & $26(29.9)$ & $24(27.6)$ & 0.33 \\
\hline 17 Sloopy stool & $15(20.8)$ & $15(20.8)$ & $21(29.2)$ & $21(29.2)$ & 0.477 \\
\hline 18 Diarrhea after intake of oil food & $10(13.5)$ & $16(21.6)$ & $21(28.4)$ & $27(36.5)$ & 0.014 \\
\hline 19 Fear of cold & $38(25.3)$ & $34(22.7)$ & $37(24.7)$ & $41(27.3)$ & 0.769 \\
\hline $\begin{array}{c}20 \text { Soreness and weakness of } \\
\text { waist and knees }\end{array}$ & $48(25.7)$ & $41(21.9)$ & $53(28.3)$ & $45(24.1)$ & 0.337 \\
\hline 21 Tinnitus & $31(29.2)$ & $25(23.6)$ & $27(25.5)$ & $23(21.7)$ & 0.623 \\
\hline 22 Frequent urination/night urination & $30(26.5)$ & $21(18.6)$ & $35(31.0)$ & $27(23.9)$ & 0.153 \\
\hline 23 Redness, hotness or anxiety & $24(25.0)$ & $18(18.8)$ & $27(28.1)$ & $27(28.1)$ & 0.383 \\
\hline
\end{tabular}

but the improvements among $1^{\text {st }}$ course, $2^{\text {nd }}$ course and the $3^{\text {rd }}$ course were similar $(P>0.05)$ (Table 15, Figure 17).

3) The percentage of spontaneous sweating was $32.9 \%$ at baseline, it was declined to $12.2 \%$ at $1^{\text {st }}$ course, $28.0 \%$ at $2^{\text {nd }}$ course, $26.8 \%$ at $3^{\text {rd }}$ course, the proportion of 3 courses after treatment compared with baseline showed reduce significantly $(P<0.05)$ (Table 14$)$. The percentage of $1^{\text {st }}$ course was statistically different compared with baseline $(P<0.001)$, there were no improvement compare $2^{\text {nd }}$ course and $3^{\text {rd }}$ course with baseline (All $P>0.05$ ) (Table 15), which indicated that the $1^{\text {st }}$ course has improved the symptoms of spontaneous sweating (Figure $18)$. 


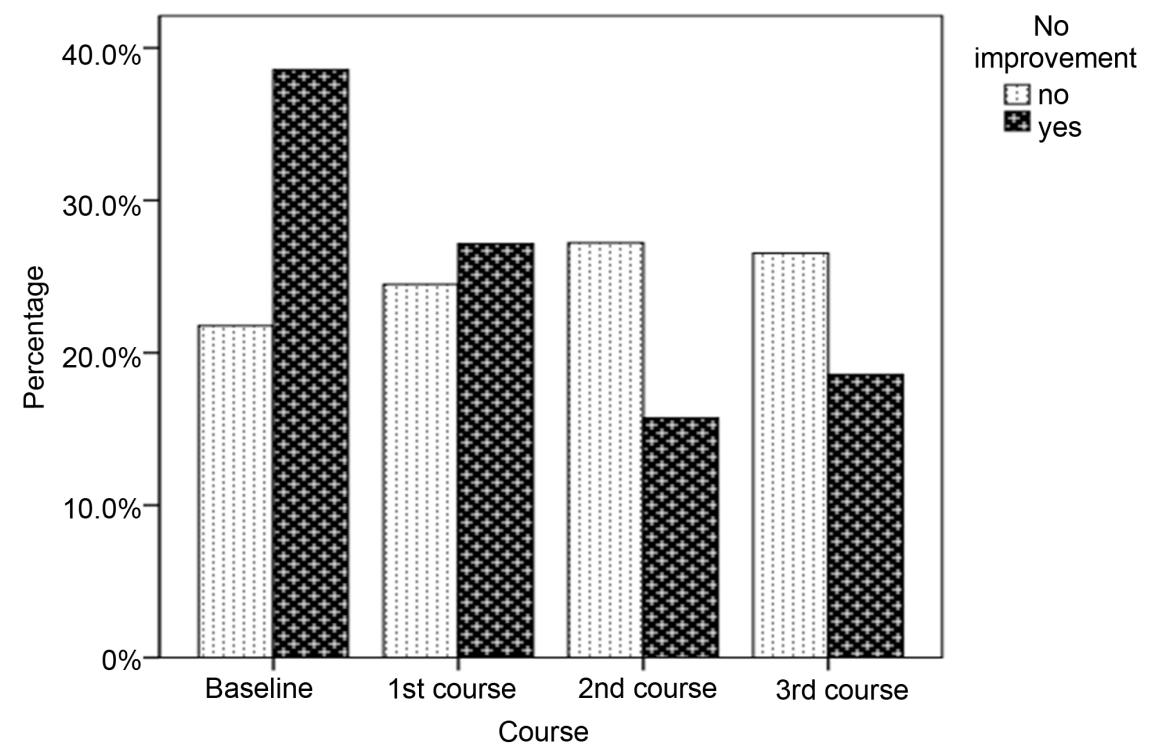

Figure 15. The percentages of asthma have no improvement.

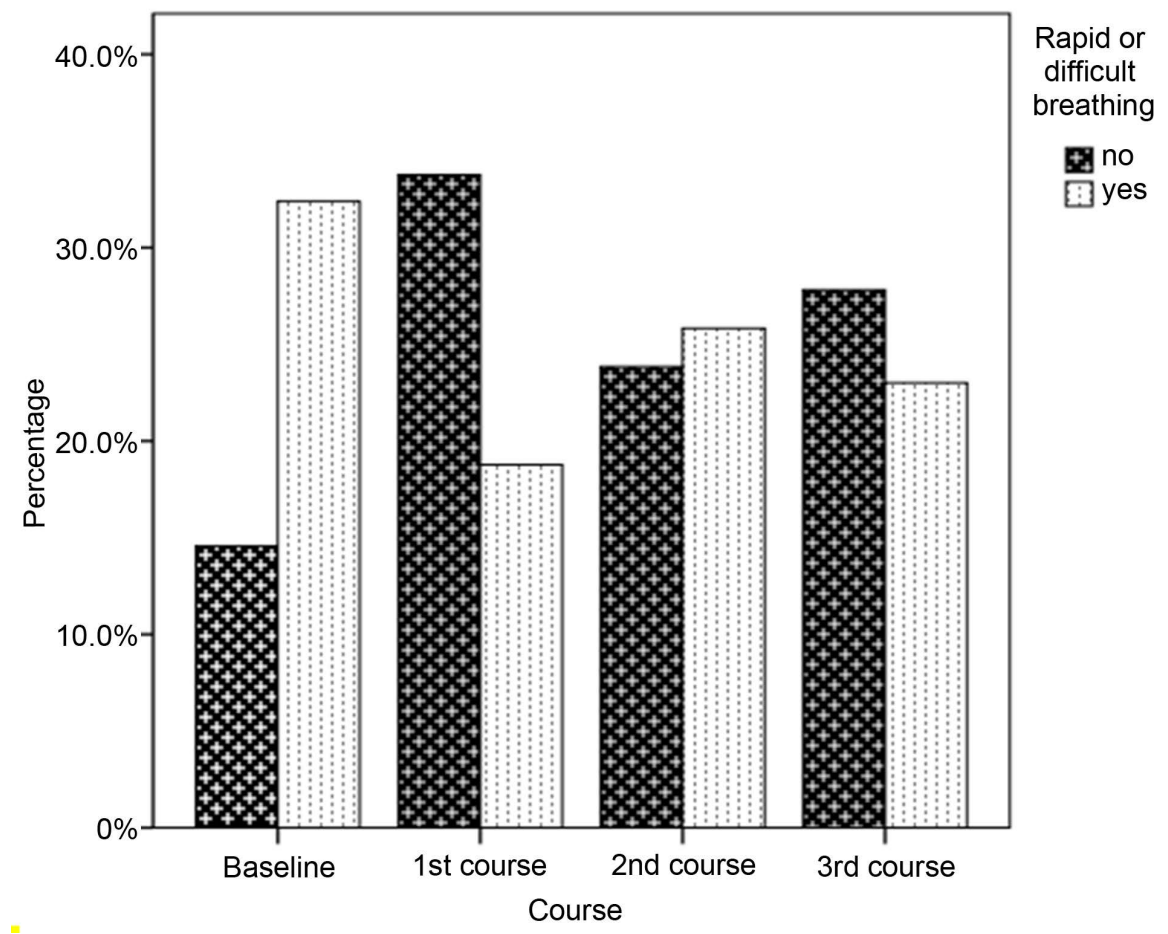

Figure 16. The percentage of rapid or difficult breathing during Tianjiu Therapy.

4) The percentage of lassitude was $38.7 \%$ at baseline, decreased to $18.2 \%$ at $1^{\text {st }}$ course, $19.0 \%$ at $2^{\text {nd }}$ course, $24.1 \%$ at $3^{\text {rd }}$ course, the proportion of 3 courses compared with baseline were significantly reduced $(P<0.05)$ (Table 14$)$. The $1^{\text {st }}$ course and the $2^{\text {nd }}$ course improved significantly (All $P<0.001$ ), and the $3^{\text {rd }}$ course improved sharply $(P<0.01)$, there were no statistical difference among $1^{\text {st }}$ course, 2 nd course and $3^{\text {rd }}$ course $(P>0.05)$ (Table 15$)$, which indicated that $1^{\text {st }}$ course, $2^{\text {nd }}$ course and $3^{\text {rd }}$ course have similar improvements with symptoms of lassitude, but $1^{\text {st }}$ course and $2^{\text {nd }}$ course have a better improvement tendency than 


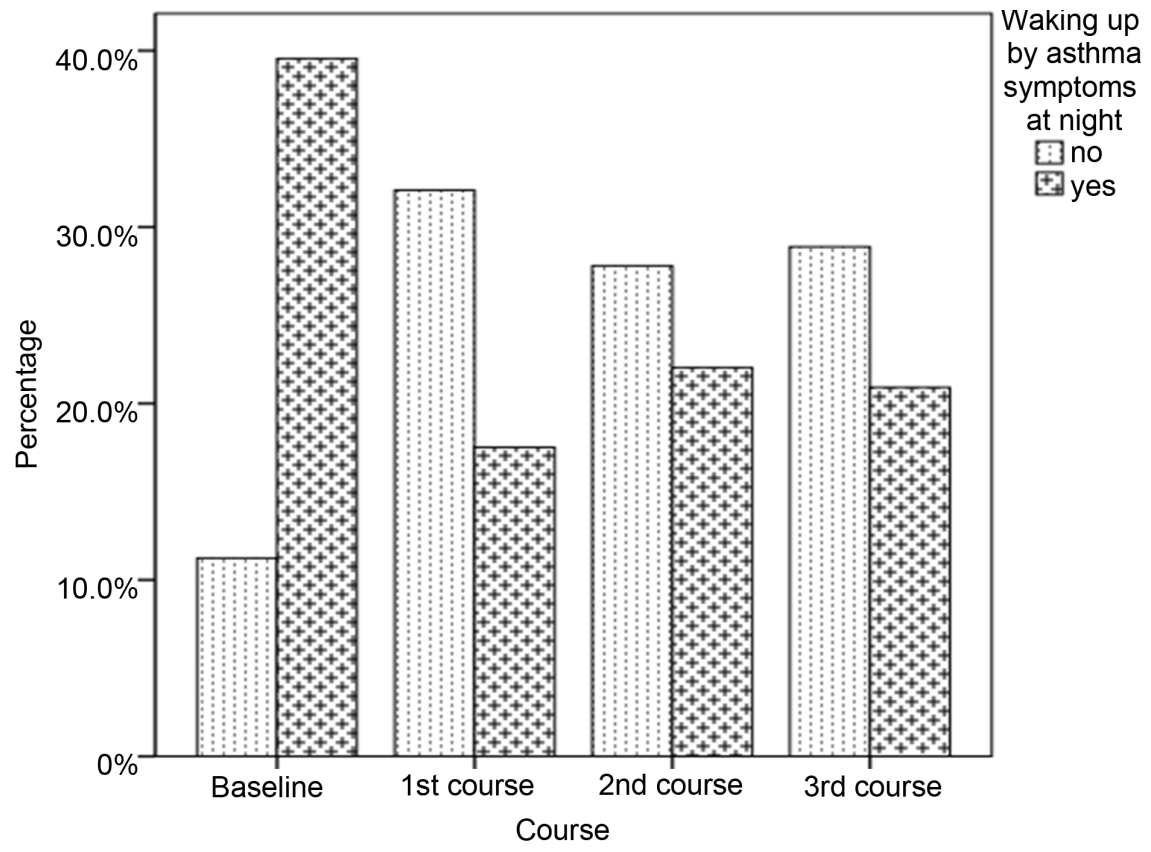

Figure 17. The percentage of waking up by asthma.

Table 15. Twenty-three clinic symptoms of Chinese Medicine.

\begin{tabular}{|c|c|c|c|c|c|c|c|}
\hline & $\begin{array}{c}\text { Baseline \& } \\
\text { the } 1^{\text {st }} \\
\text { course }\end{array}$ & $\begin{array}{l}\text { Baseline \& } \\
\text { the } 2^{\text {nd }} \\
\text { course }\end{array}$ & $\begin{array}{c}\text { Baseline \& } \\
\text { the } 3^{\text {rd }} \\
\text { course }\end{array}$ & $\begin{array}{l}\text { The } 1^{\text {st }} \\
\text { course } \& \\
\text { the } 2^{\text {nd }} \\
\text { course }\end{array}$ & $\begin{array}{l}\text { The } 1^{\text {st }} \\
\text { course \& } \\
\text { the } 3^{\text {rd }} \\
\text { course }\end{array}$ & $\begin{array}{l}\text { The } 2^{\text {nd }} \\
\text { course \& } \\
\text { the } 3^{\text {rd }} \\
\text { course }\end{array}$ & \\
\hline \multirow{2}{*}{$\begin{array}{l}\text { Rapid or diffi- } \\
\text { cult breathing }\end{array}$} & $-4.143^{\mathrm{b}}$ & $-2.160^{\mathrm{b}}$ & $-3.015^{b}$ & $-2.402^{c}$ & $-1.521^{\mathrm{c}}$ & $-1.061^{\mathrm{b}}$ & $Z$ value \\
\hline & $0.000^{\# \# \#}$ & $0.031^{\#}$ & $0.003^{\# \#}$ & $0.016^{\#}$ & 0.128 & 0.289 & $P$ value \\
\hline \multirow{2}{*}{$\begin{array}{l}\text { Wake up by } \\
\text { asthma symp- } \\
\text { toms }\end{array}$} & $-5.571^{\mathrm{b}}$ & $-4.522^{\mathrm{b}}$ & $-5.032^{\mathrm{b}}$ & $-1.333^{\mathrm{b}}$ & $-1.029^{c}$ & $-0.408^{\mathrm{b}}$ & $Z$ value \\
\hline & $0.000^{\# \# \#}$ & $0.000^{\# \# \#}$ & $0.000^{\# \# \#}$ & 0.182 & 0.303 & 0.683 & $P$ value \\
\hline \multirow{2}{*}{$\begin{array}{c}\text { Spontaneous } \\
\text { sweating }\end{array}$} & $-3.545^{\mathrm{b}}$ & $-0.853^{\mathrm{b}}$ & $-1.000^{\mathrm{b}}$ & $-2.711^{\mathrm{c}}$ & $-2.588^{c}$ & $-0.200^{\mathrm{b}}$ & $Z$ value \\
\hline & $0.000^{\# \# \#}$ & 0.394 & 0.317 & $0.007^{\# \#}$ & $0.011^{\#}$ & 0.841 & $P$ value \\
\hline \multirow{2}{*}{ Lassitude } & $-4.320^{\mathrm{b}}$ & $-4.025^{\mathrm{b}}$ & $-3.244^{\mathrm{b}}$ & $-1.92^{c}$ & $-1.461^{\mathrm{c}}$ & $-1.135^{c}$ & $Z$ value \\
\hline & $0.000^{\# \# \#}$ & $0.000^{\# \# \#}$ & $0.001^{\# \#}$ & 0.847 & 0.144 & 0.178 & $P$ value \\
\hline \multirow{2}{*}{$\begin{array}{l}\text { Reduce of } \\
\text { exercise }\end{array}$} & $-2.294^{\mathrm{b}}$ & $-0.898^{c}$ & $-0.539^{c}$ & $-3.266^{c}$ & $-2.746^{\mathrm{c}}$ & $-0.343^{\mathrm{b}}$ & $Z$ value \\
\hline & $0.022^{\#}$ & 0.369 & 0.59 & $0.001^{\# \#}$ & $0.006^{\# \#}$ & 0.732 & $P$ value \\
\hline \multirow{2}{*}{$\begin{array}{l}\text { Lack of } \\
\text { strength }\end{array}$} & $-3.452^{\mathrm{b}}$ & $-3.667^{\mathrm{b}}$ & $-2.874^{\mathrm{b}}$ & $-0.200^{\mathrm{b}}$ & $-0.707^{\mathrm{c}}$ & $-0.898^{c}$ & $Z$ value \\
\hline & $0.001^{\# \#}$ & $0.000^{\# \# \#}$ & $0.004^{\# \#}$ & 0.841 & 0.48 & 0.369 & $P$ value \\
\hline \multirow{2}{*}{$\begin{array}{l}\text { Diarrhea after } \\
\text { intake of oily } \\
\text { food }\end{array}$} & $-1.342^{\mathrm{b}}$ & $-2.200^{\mathrm{b}}$ & $-3.545^{\mathrm{b}}$ & $-1.147^{\mathrm{b}}$ & $-2.200^{\mathrm{b}}$ & $-1.225^{\mathrm{b}}$ & $Z$ value \\
\hline & 0.18 & $0.028^{\#}$ & $0.000^{\# \# \#}$ & 0.251 & $0.028^{\#}$ & 0.221 & $P$ value \\
\hline
\end{tabular}

Noted: a. Wilcoxon Signed-rank test. b. base on rank. c. base on negative rank.

$3^{\text {rd }}$ course (Figure 19).

5) The percentage of reduction of exercise was decreased from $26.0 \%$ at baseline to $11.0 \%$ at $1^{\text {st }}$ course, and increased to $32.9 \%$ at $2^{\text {nd }}$ course, $30.1 \%$ at $3^{\text {rd }}$ 


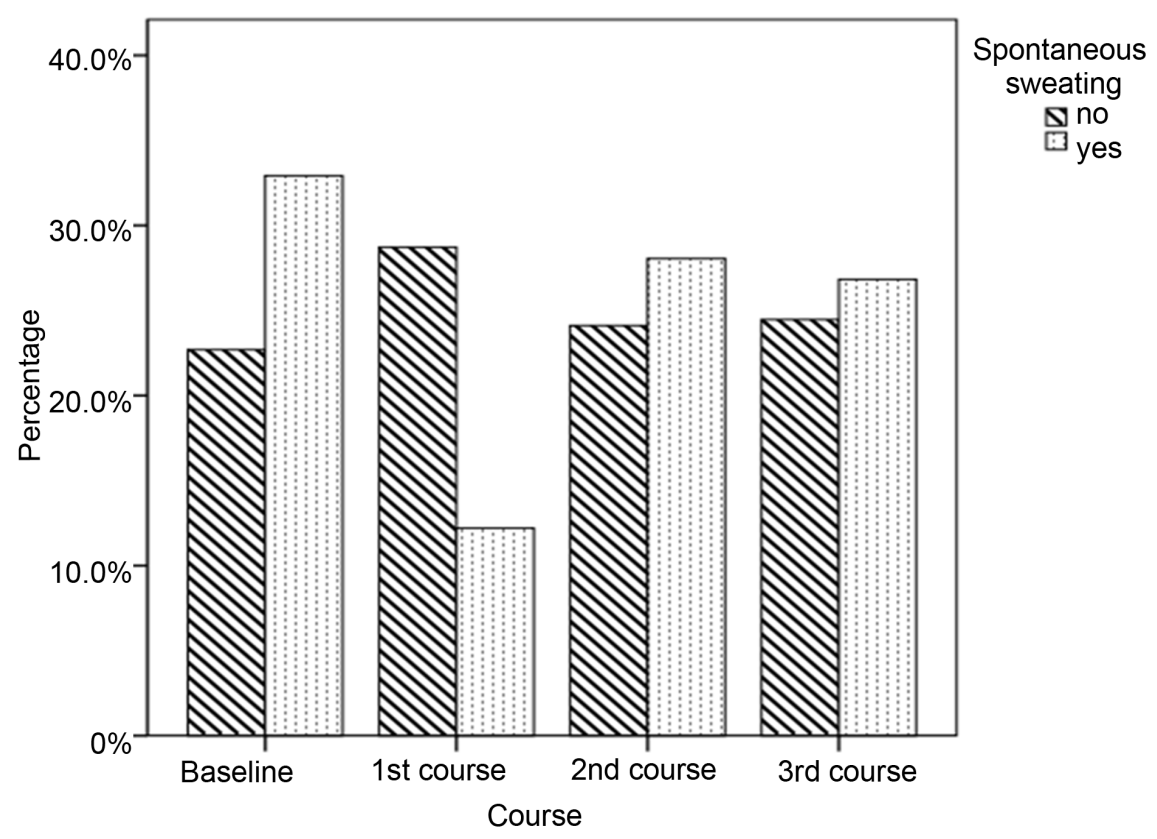

Figure 18. The percentage of spontaneous sweating.

course (Table 14). There were no improvement compared $2^{\text {nd }}$ course and $3^{\text {rd }}$ course with baseline $(P>0.05)$, but the percentage of the $1^{\text {st }}$ course improved $(P$ $<0.05$ ), which indicated the $1^{\text {st }}$ course have improved the symptoms of reduction of exercise (Table 15, Figure 20).

6) The percentage of lack of strength was declined from $33.7 \%$ at baseline to $21.5 \%$ at $1^{\text {st }}$ course, $20.9 \%$ at $2^{\text {nd }}$ course, $23.8 \%$ at $3^{\text {rd }}$ course, the proportions of 4 time points were statistical difference $(P<0.05)$ (Table 14). The improvements of $1^{\text {st }}$ course and $3^{\text {rd }}$ course were sharply (All $\left.P<0.01\right), 2^{\text {nd }}$ course was significantly $(P<0.001)$, there were no statistical difference among $1^{\text {st }}$ course, $2^{\text {nd }}$ course and the $3^{\text {rd }}$ course $(P>0.05)$, which means the improvements of $1^{\text {st }}$ course, $2^{\text {nd }}$ course and $3^{\text {rd }}$ course for symptoms of participants suffering from lack of strength were similar, and $2^{\text {nd }}$ course have a better improvement tendency (Table 15, Figure 21).

7) The percentage of diarrhea after intake of oil food was $13.5 \%$ at baseline, it was increased to $21.6 \%$ at the $1^{\text {st }}$ course, $28.4 \%$ at the $2^{\text {nd }}$ course, $36.5 \%$ at the $3^{\text {rd }}$ course, the improvements with proportion have statistical difference (All $P<$ $0.05)$ (Table 14). The percentages of the $2^{\text {nd }}$ course and the $3^{\text {rd }}$ course were statistically increased compared with baseline (All $P<0.05$ ), there was no statistical difference compared baseline with the $1^{\text {st }}$ course $(P>0.05)$, which means the $2^{\text {nd }}$ course and the $3^{\text {rd }}$ course have a little worse in symptoms of participants suffering from diarrhea after intake of oil food. (Table 15, Figure 22).

\subsubsection{Results of Lung function}

Average of FEV1 was $1.85 \pm 0.94$ at baseline, it was decreased to $1.73 \pm 0.64$ at $1^{\text {st }}$ course, $1.73 \pm 0.64$ at $2^{\text {nd }}$ course, increased to $1.92 \pm 1.51$ at $3^{\text {rd }}$ course (All $P>$ 0.05 ) (Table 3 ), which indicated there was no significant statistical improvement 


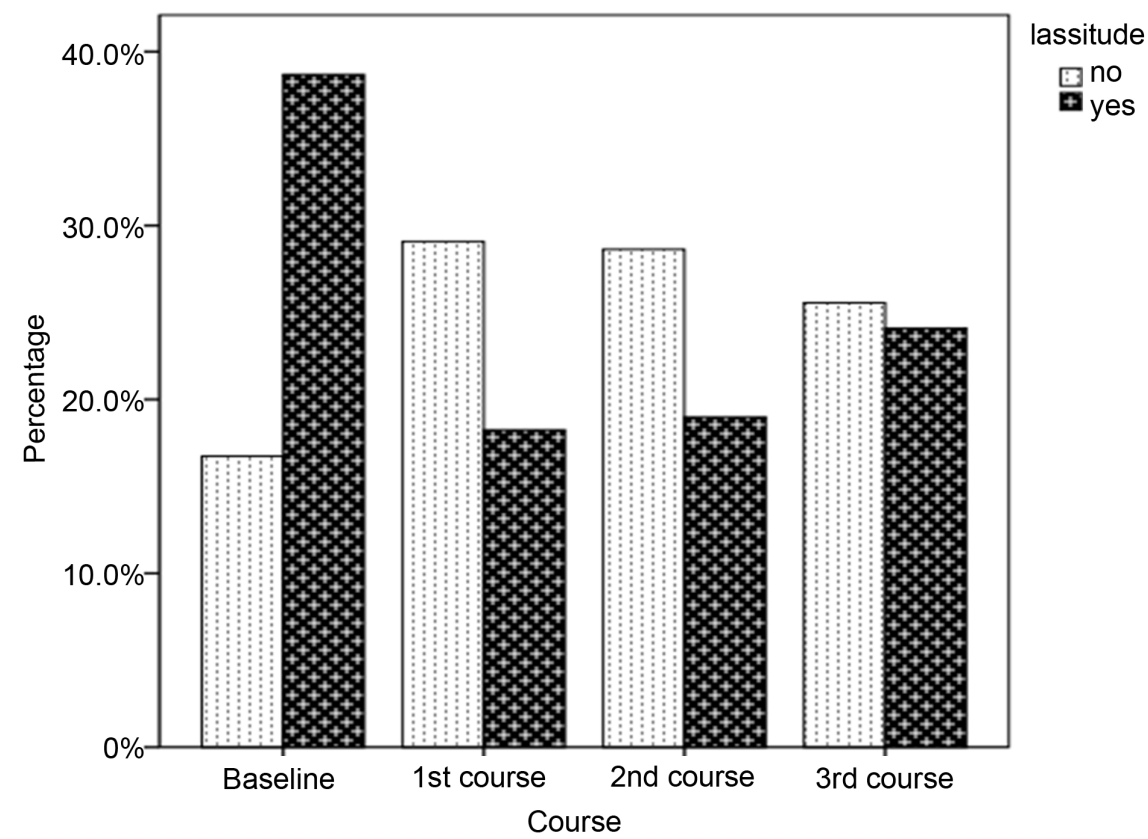

Figure 19. The percentage of participants suffered from lassitude.

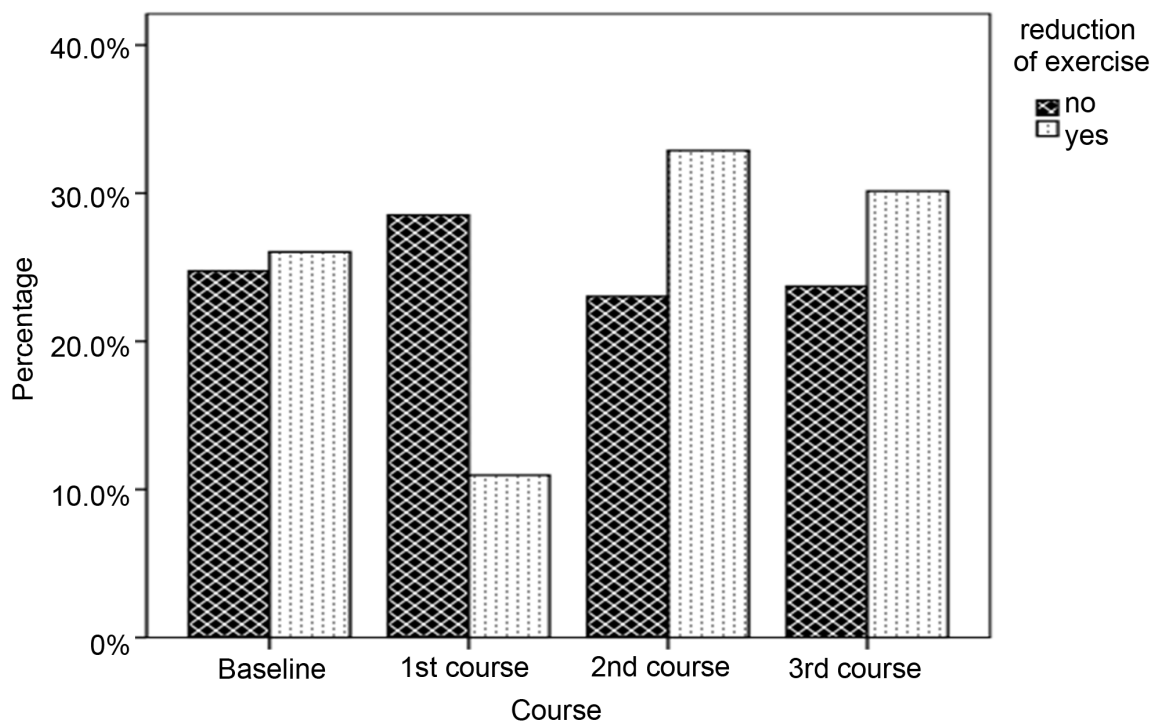

Figure 20. The proportion of participants suffered from reduction of exercise.

after any course of FEV1 for asthma participants; The percentage of $\mathrm{FEV} 1 / \mathrm{FVC}(\times 100)$ was $81.68 \pm 19.06$ in baseline, there were increased to $82.76 \pm$ 14.89 at $1^{\text {st }}$ course, $83.37 \pm 14.6$ at $2^{\text {nd }}$ course, and declined to $79.50 \pm 19.17$ at $3^{\text {rd }}$ course (All $P>0.05$ ) (Table 3 ). That means after 3 courses of Tianjiu therapy, there was no significant statistical improvement of FEV1/FVC for participants.

\subsubsection{Results of ACT}

The average total scores of participants was $19.55 \pm 4.87$ at baseline, and increased to $20.55 \pm 1.37$ at $1^{\text {st }}$ course, $20.91 \pm 3.48$ at $2^{\text {nd }}$ course, and $21.00 \pm 2.93$ at $3^{\text {rd }}$ course, there was no statistical difference among the results (All $P>0.05$ ) 


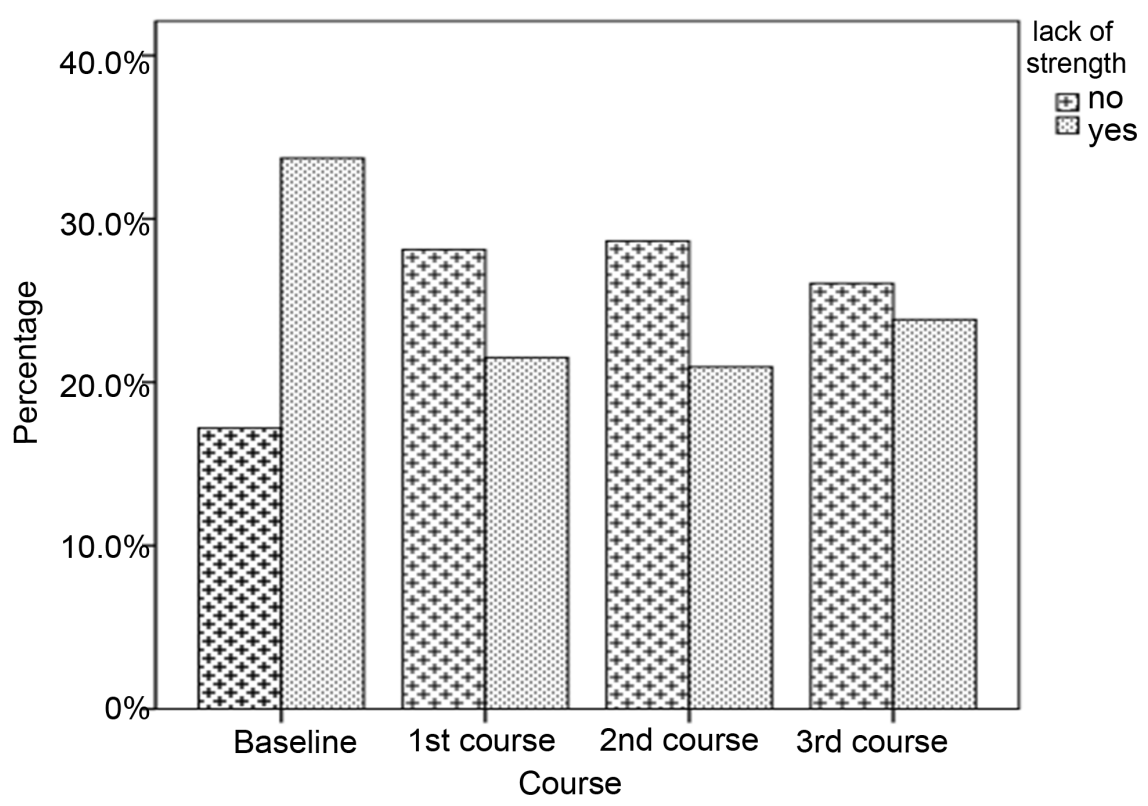

Figure 21. The proportion of participants suffered from lack of strength.

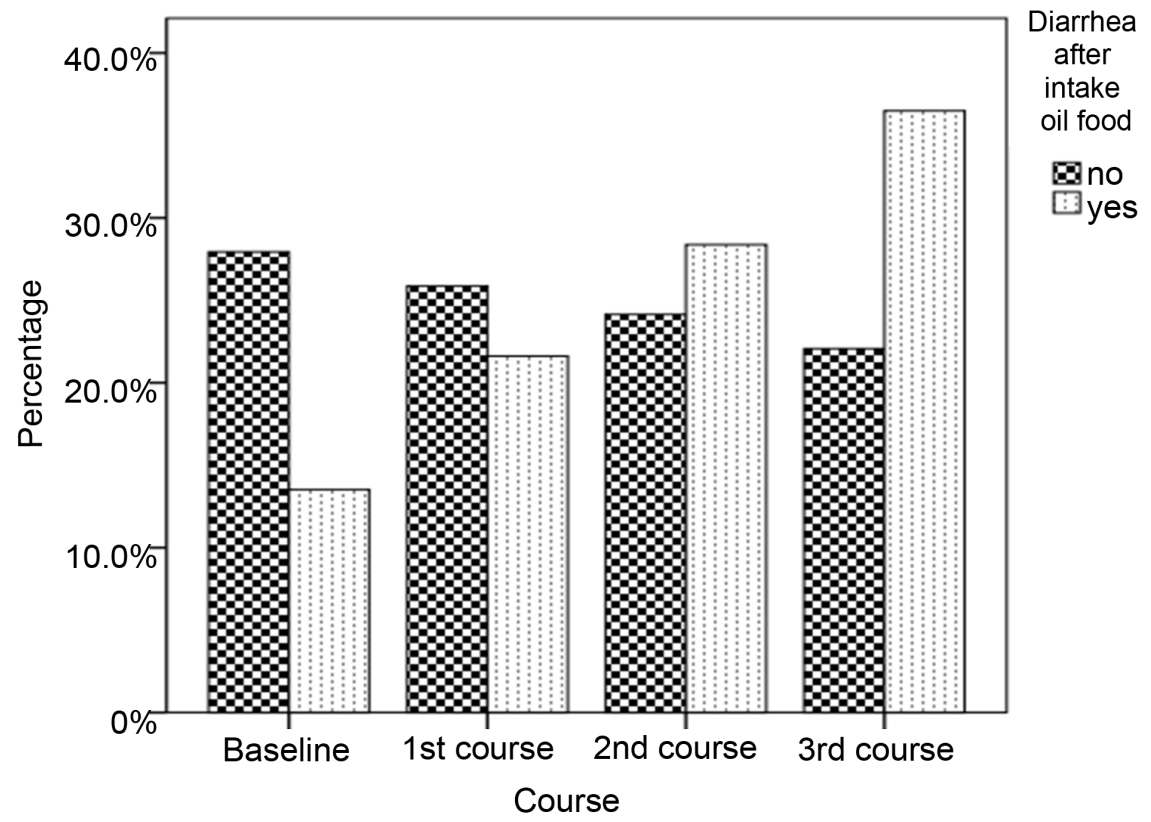

Figure 22. The proportion of participants suffered from Diarrhea after intake of oil food.

(Table 16), which means that there was no significant improvement for the 5 symptoms.

\section{Discussion}

In the first previous study (HKCTR-1128), Tianjiu Therapy has shown substantial improvements in the medication need after treatment, included the number of symptoms which frequency appeared in asthma patients, and the number of days with asthma-related symptoms. There was nothing different between Tianjiu Therapy group and placebo group after the $3^{\text {rd }}$ treatment immediately, but 
Table 16. Efficacy observation on Tianjiu therapy for asthma.

\begin{tabular}{|c|c|c|c|c|c|}
\hline No. (\%) & Baseline & The 1st course & The 2 nd course & The 3 rd course & $P$ value \\
\hline \multicolumn{6}{|c|}{$\begin{array}{l}\text { Q1:In the past } 4 \text { weeks, how much of the time did your asthma keep you from } \\
\text { getting as much done at work, school or at home? }\end{array}$} \\
\hline All the time & 0 & 2 & 1.1 & 1.1 & \\
\hline Most of the time & 18.2 & 4.1 & 4.1 & 4.4 & \\
\hline Some of the time & 0 & 8.2 & 8.2 & 9.9 & 0.62 \\
\hline A little of the time & 9.1 & 8.2 & 8.2 & 12.1 & \\
\hline None of the time & 72.7 & 77.6 & 77.6 & 72.5 & \\
\hline
\end{tabular}

Q2: During the past 4 weeks, how often have you had shortness of the breath?

$\begin{array}{lcccc}\text { All the time } & 9.1 & 6.1 & 3.3 & 7.7 \\ \text { Most of the time } & 18.2 & 16.3 & 11 & 8.8 \\ \text { Some of the time } & 9.1 & 10.2 & 13.2 & 9.9 \\ \text { A little of the time } & 18.2 & 20.4 & 34.1 & 27.5 \\ \text { None of the time } & 45.5 & 46.9 & 38.5 & 46.2\end{array}$

Q3: During the past 4 weeks, how often did you asthma symptoms (wheezing, coughing, shortness of breath, chest tightness or pain) wake you up at night or earlier than usual in the morning?

$\begin{array}{cccccc}\text { All the time } & 0 & 8.2 & 4.4 & 13.2 & \\ \text { Most of the time } & 18.2 & 4.1 & 7.7 & 5.5 & \\ \text { Some of the time } & 9.1 & 8.2 & 12.1 & 6.6 & 0.56 \\ \text { A little of the time } & 9.1 & 20.4 & 17.6 & 16.5 & \\ \text { None of the time } & 63.6 & 59.2 & 58.2 & 58.2\end{array}$

Q4: During the past 4 weeks, how often have you used your rescue inhaler or nebulizer medication (such as albuterol)?

$\begin{array}{lccccc}\text { All the time } & 9.1 & 8.2 & 11 & 11 & \\ \text { Most of the time } & 18.1 & 30.6 & 15.4 & 23.1 & \\ \text { Some of the time } & 9.1 & 2 & 6.6 & 9.9 & 0.72 \\ \text { A little of the time } & 18.2 & 14.3 & 16.5 & 9.9 & \\ \text { None of the time } & 45.5 & 44.9 & 50.5 & 46.2\end{array}$

Q5: How would you rate your asthma control during the past 4 weeks?

$\begin{array}{ccccc}\text { All the time } & 0 & 0 & 2.2 & 1.1 \\ \text { Most of the time } & 9.1 & 6.1 & 6.6 & 7.7 \\ \text { Some of the time } & 36.4 & 18.4 & 26.4 & 24.2 \\ \text { A little of the time } & 45.5 & 49 & 46.7 & 53.8 \\ \text { None of the time } & 9.1 & 26.5 & 18.7 & 13.2\end{array}$

Total: The average total scores of 5 questions above.

$19.55 \pm 4.87 \quad 21.55 \pm 1.37 \quad 20.91 \pm 3.48 \quad 21.00 \pm 2.93 \quad 0.427$ 
the effect of Tianjiu Therapy has increasing trend than placebo group in the four-time followup; In the second previous study, it had proved that both 2-course Tianjiu Therapy and one-course Tianjiu Therapy significantly reduced the number of symptoms which frequently appeared in asthma patients and medication need in participants with chronic asthma as compared with baseline. The $2^{\text {nd }}$ course Tianjiu Therapy was less sensitive than the first course Tianjiu Therapy for chronic asthma, however, the second course treatment still plays a role in solidating the curative effect of Tianjiu Therapy in the treatment of asthma. Therefore, this study aimed to explore the efficiency if would get better as the courses get longer for asthma patients of Tianjiu Therapy in Sanfu days and tried to explore the optimal efficiency course. As a result, participants with asthma who received Tianjiu therapy in Sanfu days have improved with the days for asthma attack, asthma related process when asthma attacked including Inter-grated Chinese medicine and Western Medicine Clinic admitted, times of Inter-grated Chinese medicine and Western Medicine Clinic admitted, times of solving by own medicine and persistent medicine, and the symptom of waking up by asthma symptoms, lassitude, lacking of strength similarly in 3 courses compared with no treatment (All $P<0.05$ ), these results showed that as the course get longer, the efficiency did not become better, instead, efficiency kept a stable status; the frequency of asthma attacked was much more improved in the $2^{\text {nd }}$ course and the $3^{\text {rd }}$ course than in the $1^{\text {st }}$ course (All $P<0.05$ ), it means the efficiency kept a stable improvement in the $2^{\text {nd }}$ course and the $3^{\text {rd }}$ course; in some results like admitted to the hospital, solved by persistent medication when asthma attack, the frequency of Chinese herbal medicine, and asthma was under controlled were improved in the $2^{\text {nd }}$ course and the $3^{\text {rd }}$ course; in some results like admitted to A \& E, other treatment except bronchodilator and Chinese medicine and Western Medicine were improved in the $3^{\text {rd }}$ course; and the frequency of bronchodilator used was improved better in the $2^{\text {nd }}$ course than the $1^{\text {st }}$ course $(P<0.05)$. All above showed that as the course get longer, more symptoms were improved. And because the time points were chosen 1 year after Tianjiu Therapy, it proved that the efficiency was last for almost 1 year. But the symptoms of spleen-qi-deficient included spontaneous sweating, reduce of exercise, diarrhea after intake of oily food were not improved as the course get longer. One of lung-qi-deficient symptoms like rapid or difficult breathing was improved better in the $1^{\text {st }}$ course than in the $2^{\text {nd }}$ course and the $3^{\text {rd }}$ course. The last but not the least, no changes occurred in pulmonary function and ACT for 3 course compared with baseline, but have increasing trend in total score for ACT.

\section{Conclusion}

From the result of this study, although the symptoms of spleen-qi-deficient including spontaneous sweating, reduce of exercise, diarrhea after intake of oily food were not improved as the course get longer, most symptoms other than that were improved when the course get longer. The results suggest that patients with chronic asthma who were receiving Tianjiu Therapy in Sanfu Days consecutively 
for three years can be benefited better.

\section{Acknowledgements}

The study was financially supported by Health and Medical Research Fund (HMRF) from The Food and Health Bureau of Hong Kong Special Administrative Region (Project Code: 260870650).

\section{References}

[1] Zhou, J.M., Wei, F., Liu, M.M., Xu, S.W., Yang, Y. and Zhang, B.M. (2014) Advances in Experimental Study on Acupuncture Treatment of Bronchial Asthma. Chinese Journal of Basic Medicine in Traditional Chinese Medicine, 5, 709-710.

[2] Jiang, H.Q. (2015) Efficiency Analysis of Chinese Medicine Therapy in the Treatment of Bronchial Asthma. Clinical Journal of Chinese Medicine, 7, 64-65.

[3] Lu, D.W. (1996) The Newest Chinese and Western Medicine Diagnosis and Treatment of Rhinitis and Asthma. China Traditional Medicine Press, Beijng, 486.

[4] Li, Z.H. (2010) Treatment and Care of Tianjiu Therapy on Sanfu Days for 10 Cases of Bronchial Asthma Patients. Guangming Journal of Chinese Medicine, 10, 1929.

[5] Zhu, L.B., Lo, K.C. and Li, L. (2014) The Analysis of Factors Influencing TianJiu Therapy on Asthma. Guangming Journal of Chinese Medicine, 8, 1794-1796.

[6] Li, L.P., Bao, Y.H. and Chu, J.M. (2012) Effects Observation of Prevention and Treatment for Children's Bronchial Asthma in Summer by Acupoint Application Therapy. Chinese Archives of Traditional Chinese Medicine, 2, 376-378.

[7] Wei, T. (2004) Observation on Acupoint Application in the Hottest Summer Days for Asthmatic Diseases. Medical Information, 180, 177.

[8] Ma, H., Xiao, X.T. and Zheng, F.R. (2009) Clinical Observation on Treatment of Bronchial Asthma Remission of Proposed Prescriptions Cooperation with Tianjiu Therapy on Sanfu Days. Journal of Traditional Chinese Medicine, 6, 537-538.

[9] Qi, C.J. and Huang, G.Q. (2010) Sticking Therapy Chinese Medicinal Natural Moxibustion Cough Asthma. Journal of Acupuncture and Tui Na Science, 3, 189-190. https://doi.org/10.1007/s11726-010-0403-2

[10] Zhu, Y., Deng, P.Y. and Miao, F.R. (2012) The Influence of Dog Days Acupoint Sticking of Bronchial Asthma Patients in Serum IL-5, IL-10 and the ECP. Guangxi Journal of Traditional Chinese Medicine, 6, 20-22.

[11] Chen, C.-M., He, H., Ke, W.-M., Lv, J.-B., Wu, J.-Q. and Zhou, X.-H. (2014) Standardized Study of Vesiculation Moxibustion Therapy for Bronchial Asthma. Shanghai Journal of Acupuncture and Moxibustion, 11, 1013-1015.

[12] Xue, N. (2014) Clinic Observation on Treating Bronchial Asthma by the Tianjiu Therapy. Clinical Journal of Chinese Medicine, 17, 47-48.

[13] He, Q.J. (2013) Day Moxibustion Treatment of Chronic Bronchitis, 400 Cases of Clinical Observation. Journal of Practical Traditional Chinese Internal Medicine, 6, 60-61.

[14] Yao, Y. (2011) Tianjiu Therapy on 98 Patients of Chronic Asthma. Journal of Emergency in Traditional Chinese Medicine, 4, 652.

[15] Zhu, L.B., Zhang, W., Wong, V., Eric, Z., Lao, L.-X., Lo, K.C., Chan, W.C., Yau, T. and Li, L. (2016) Randomized Trial of Acupoints Herbal Patching in Sanfu Days for Asthma in Clinical Remission Stage. Clinical and Translational Medicine, 5, 5. http://www.clintransmed.com/content/5/1/5 
https://doi.org/10.1186/s40169-016-0084-7

[16] Zhu, L.B., Zhang, W., Wong, V., Eric, Z., Lo, K.C., Chan, W.C., Yau, T. and Li, L. (2014) Two Years versus One Year of Tianjiu Therapy in Sanfu Days for Chronic Asthma: A Clinical Efficacy Observation Trial. Evidence-Based Complementary and Alternative Medicine, Article ID 807598. https://doi.org/10.1155/2014/807598

Submit or recommend next manuscript to SCIRP and we will provide best service for you:

Accepting pre-submission inquiries through Email, Facebook, LinkedIn, Twitter, etc. A wide selection of journals (inclusive of 9 subjects, more than 200 journals)

Providing 24-hour high-quality service

User-friendly online submission system

Fair and swift peer-review system

Efficient typesetting and proofreading procedure

Display of the result of downloads and visits, as well as the number of cited articles Maximum dissemination of your research work

Submit your manuscript at: http://papersubmission.scirp.org/

Or contact cm@scirp.org 